\title{
THE NATIONAL ENERGY BOARD: Regulation of ACCess to Oil Pipelines
}

\author{
JENNIFER HOCKING*
}

In the past few years, a number of long-distance oil pipelines have been proposed in Canada - Northern Gateway, the Trans Mountain Expansion, Keystone, and the Energy East Project. This article describes the criteria used by the National Energy Board in approving the allocation of capacity in oil pipelines to firm service contracts while requiring that a reasonable percentage of capacity is allocated for uncommitted volumes (common carriage). It explains the economic theory related to regulation of access to major oil pipelines. It reviews and analyzes relevant $N E B$ decisions, which show that the NEB supports wellfunctioning competitive markets, but will exercise its discretion to resolve complaints where markets are not functioning properly. The article also explains the economic significance of the proposed long-distance oil pipelines to Canada and Alberta despite the current low price of crude oil. The article concludes with recommendations for a written NEB policy regarding access to capacity in oil pipelines.

\section{TABLE OF CONTENTS}

I. SignificAnCe of Proposed OIL Pipelines

TO THE CANADIAN ECONOMY $\ldots \ldots \ldots \ldots \ldots \ldots \ldots \ldots \ldots \ldots . \ldots \ldots$

A. Pipelines NeEded Despite Low PRICE OF OIL $\ldots \ldots \ldots \ldots 780$

B. SHIPPING OF OIL BY RaIL $\ldots \ldots \ldots \ldots \ldots \ldots \ldots \ldots \ldots \ldots \ldots \ldots$

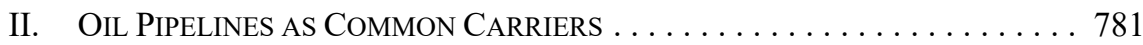

A. The NATURe of Common CARRIERS $\ldots \ldots \ldots \ldots \ldots \ldots \ldots . \ldots 78$

B. COMMON CARRIAgE OBligation SUBJECT

TO REASONABLENESS TEST . . . . . . . . . . . . . . . . 783

C. Why Were Oil Pipelines ORiginally Designated

AS COMMON CARRIERS? . . . . . . . . . . . . . . . . . . . . . 784

III. Major Long-Distance Oil Pipelines Today $\ldots \ldots \ldots \ldots \ldots \ldots 785$

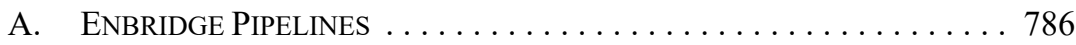

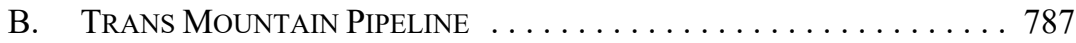

C. SPectra Energy Express-Platte $\ldots \ldots \ldots \ldots \ldots \ldots \ldots \ldots . \ldots 788$

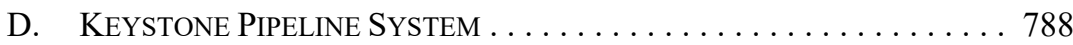

E. Proposed Energy East Project $\ldots \ldots \ldots \ldots \ldots \ldots \ldots \ldots$

F. The DeVelopment OF PIPE-ON-PIPE

COMPETITION FOR OIL PIPELINES $\ldots \ldots \ldots \ldots \ldots \ldots$. . . . . . . 790

IV. ECONOMIC THEORY: WHY SHOULD THE NEB

REgulate ACCESS to OIL Pipelines? . . . . . . . . . . . . . . . 790

A. Competition and Natural Monopolies $\ldots \ldots \ldots \ldots \ldots . . .791$

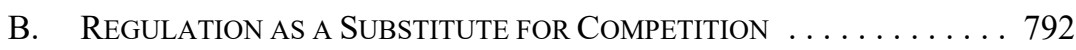

C. Regulation to Provide Open ACCEss

TO TRANSMISSION PIPELINES . . . . . . . . . . . . . . . . . . . . 792

Jennifer Hocking has practiced in energy and aboriginal law for over nineteen years, including a contract with the National Energy Board in 2000. She has recently completed a Master of Laws at the University of Calgary on the regulation of access to crude oil and natural gas pipelines. 
D. OBJECTIVES FOR REGULATION OF

OIL AND NATURAL GAS PIPELINES . . . . . . . . . . . . . . . . . 793

V. The NEB: Policy AND DECISIONS REGARDING

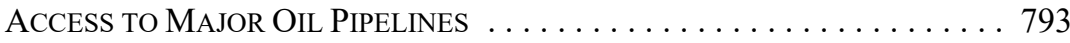

A. NEB Policy Statements: COMPETITIVE

OIL AND GAS TRANSPORTATION MARKETS . . . . . . . . . . . . . . . 793

B. Deregulation AND Open ACCESS to

OIL AND GAS TRANSMISSION PIPELINES . . . . . . . . . . . . . . 794

C. FIRM CONTRACTS NOT INCONSISTENT WITH

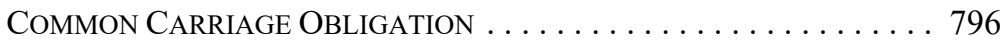

D. NEB DECISIONS REGARDING

FIRM SERVICE IN OIL PIPELINES $\ldots \ldots \ldots \ldots \ldots \ldots \ldots$. . . . . . 798

E. Do OIL PiPELINE COMPANIES TODAY

HaVE Market Power? . . . . . . . . . . . . . . . . . . . . . . . 804

F. LOWER FIRM SERVICE TOLLS FOR COMMITTED SHIPPERS

ARE NOT UNJUST DiSCRIMINATION . . . . . . . . . . . . . . 809

G. UniQue CASES REgARDING CAPACITY IN OIL PIPELINES

AND THE NEB APPROACH $\ldots \ldots \ldots \ldots \ldots \ldots \ldots \ldots \ldots$

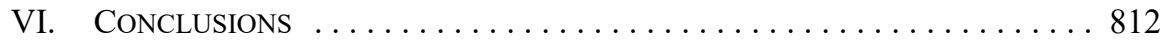

A. RECOMMENDATIONS FOR A
DRAFT MEMORANDUM OF GUIDANCE $(\mathrm{MOG}) \ldots \ldots \ldots \ldots \ldots . \ldots 13$

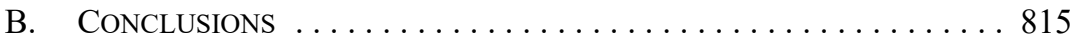

\section{Significance of Proposed Oil Pipelines TO THE CANADIAN ECONOMY}

Access to capacity in oil pipelines is currently an issue of major significance to the Canadian economy. Oil exports are an important part of the Canadian economy. ${ }^{1}$ Western Canadian crude oil production is projected to grow by 156,000 barrels per day (bpd) until 2020 , and by $85,000 \mathrm{bpd}$ from 2020 to 2030 . $^{2}$ Additional oil pipeline export capacity from Alberta is needed in order to accommodate forecasted increases in oil production. ${ }^{3}$

The majority of conventional Canadian oil is produced in the Western Canadian Sedimentary Basin (WCSB), which is located in Alberta, northeastern British Columbia, Saskatchewan, and parts of Manitoba and the Northwest Territories. ${ }^{4}$ Until the middle of the last decade, Alberta crude oil sold in the United States midwest traded at a premium to world prices because it was closer to markets than international oil, which had to be shipped from

Oil and gas constitutes approximately $\$ 133$ billion or 7.5 percent of the total Canadian Gross domestic product (GDP). Oil and gas exports constitute $\$ 117$ billion of Canadian domestic merchandise exports: Natural Resources Canada, Energy Market Fact Book 2014-2015 (Ottawa: NRC, 2014) at 4-5, online: $<$ www.nrcan.gc.ca/sites/www.nrcan.gc.ca/files/energy/files/pdf/2014/14-0173EnergyMarketFacts_e. pdf>. Canadian Association of Petroleum Producers, Crude Oil: Forecast, Markets \& Transportation (June 2015) at 5, online: <www.capp.ca/forecast/Pages/default.aspx> [Crude Oil Forecast].

See Dinara Millington, "Oil Sands Economic Outlook" (Presentation delivered at the Oil Sands Symposium, Calgary, 25-26 November 2014) at 22 [Oil Sands Symposium Presentation]; Dinara Millington \& Jon Rozhon, Pacific Access: Part I - Linking Oil Sands Supply to New and Existing Markets (Calgary: Canadian Energy Research Institute, 2012) at 11. 
tidewater to the middle of the continent. ${ }^{5}$ However, since 2010, the US midwest has had a glut of oil. ${ }^{6}$ Canada cannot rely on continuing to sell the majority of its exported crude oil to the US midwest. Canada will therefore need to find new foreign markets for its oil. If new foreign markets cannot be accessed for Canadian crude oil, future growth in Canadian crude oil production will be limited, ${ }^{7}$ with significant impacts on the Canadian economy.

Currently, pipeline capacity to tidewater is tight, meaning that Alberta oil cannot reach overseas markets. This means that Alberta oil has traded at a significant discount relative to North American and world oil prices in recent years. The price discounts can also result in significantly lower tax revenues and royalties for both federal and provincial governments, and lower netbacks for oil producers. The Alberta government relies on energy for a significant portion of its revenues. ${ }^{8}$

From 2010 to 2012, there was sufficient pipeline capacity for oil to reach the Cushing Hub in Oklahoma, but much of that oil was then placed in storage tanks at Cushing due to the shortage of pipeline capacity south to the Gulf of Mexico. Within that time frame, the price differential between Western Canada Select (WCS) heavy blend crude (Alberta heavy oil) and the Cushing Hub price of West Texas Intermediate (WTI) light crude ${ }^{9}$ widened from only a dollar in November $2010^{10}$ to a record high of $\$ 42.50$ on 14 December $2012 .{ }^{11}$ As additional pipeline capacity is added, the price differential tends to narrow until the new pipeline capacity is filled. ${ }^{12}$ Then the price differential will widen until further pipeline capacity is added. For example, the price differential was narrowed in January 2013, when pipeline capacity in the Seaway Pipeline from Cushing to the Gulf of Mexico was increased. ${ }^{13}$ In January 2014, the price differential was narrowed again when the southern leg of the Keystone pipeline system to the Gulf Coast became operational, adding further pipeline capacity to tidewater. By the second quarter (Q2) of 2014, the price differential

$5 \quad$ Andrew Leach \& Kirsten Smith, "Economist Andrew Leach and Kirsten Smith pop the notion of a 'bitumen bubble,"” Alberta Oil (10 February 2014), online: <www.albertaoilmagazine.com/2014/02/ andrew-leach-bitumen-bubble>.

6 Ibid.

$7 \quad$ Michael Holden, Pipe or Perish: Saving an Oil Industry at Risk (Calgary: Canada West Foundation, 2013) at 2 [Canada West Report]. The Canada West Foundation is an independent economic and public policy research body.

8 See e.g. former Alberta Progressive Conservative government's 2015 budget: Alberta, Treasury Board and Finance, Budget 2015: Fiscal Plan 2015-20, (Edmonton: TBF, 2015) at 60, online: < finance.alberta. ca/publications/budget/budget2015/fiscal-plan-complete.pdf $>$ [Budget 2015]; Jeffrey Jones, "Canadian crude prices see strong start to 2014," Globe and Mail (14 January 2014), online: <www.the globeandmail.com/report-on-business/canadian-crude-prices-see-strong-start-to-2015/article16335942/>. "West Texas Intermediate" is the price for light crude at the Cushing Hub in Oklahoma: see Nasdaq, "Financial Glossary: West Texas Intermediate," online: <www.nasdaq.com/investing/glossary/w/westtexas-intermediate>.

10 Marin Katusa, "Oil Price Differentials: Caught Between the Sands and the Pipelines," Forbes (21 June 2012), online: <www.forbes.com/sites/energysource/2012/06/21/oil-price-differentials-caught-betweenthe-sands-and-the-pipelines/>.

11 Yadullah Hussain, "Canadian crude price discount to WTI hits \$41," Financial Post (11 January 2013), online: <business.financialpost.com/news/energy/canadian-crude-price-discount-to-wti-hits-41> [Hussain, "WTI hits \$41"].

Katusa, supra note 10.

Capacity in the Seaway Pipeline was increased following pump station additions and modifications Seaway Crude Pipeline Company LLC is a 50/50 joint venture between Enterprise Products Partners LP and Enbridge Inc: Seaway Crude Pipeline Company LLC, "About Seaway," online: <seaway pipeline.com/>. See also Hussain, "WTI hits \$41," supra note 11. 
between WTI and WCS had narrowed further as more crude oil was shipped by rail due to constrained pipeline capacity. ${ }^{14}$ As of December 2015 , the WTI/WCS price was US $\$ 14.82 .{ }^{15}$

Developing new markets is best done by developing pipeline capacity to the west and east coasts of Canada, to the US Gulf Coast, and to the US eastern seaboard. New Asian markets can be accessed most cost effectively by pipeline to the west coast of British Columbia and by tanker from there. According to a report by the Canada West Foundation, China and India are the "fastest growing economies in the world," 16 and demand for oil in these two countries is also growing. ${ }^{17}$ In addition, the US Gulf Coast is an important market for Canadian oil, as it has numerous refineries that are equipped to process Canadian heavy crude oil. ${ }^{18}$ Further, refineries in eastern Canada are now seeking access to Canadian crude oil as imported overseas crude oil becomes more expensive. ${ }^{19}$

Pipelines are the safest, most cost-effective, and most energy efficient way for Canadian oil to reach markets, ${ }^{20}$ despite opposition to new pipelines, pipeline expansions, and pipeline reversals based on environmental concerns. ${ }^{21}$ Russia and the Middle East, as well as other regions, are also taking steps to secure supply links to Asia, including China. ${ }^{22}$ If Canada cannot provide reliable crude oil supply to Asia soon, the opportunity will be lost to other world players, and the Canadian economy will be impacted.

\section{A. Pipelines Needed Despite Low Price OF OIL}

Additional oil pipeline capacity is required despite the current low world price of crude oil. Between June 2014 and March 2015 the world price of crude oil fell by over 50 percent for a number of reasons. ${ }^{23}$ While some oil projects have been deferred, ${ }^{24}$ many developments will continue to produce oil over the coming years. Oil sands projects require large amounts of capital, and take several years to construct, ${ }^{25}$ generally they will produce oil for many years. As a result, oil sands production from existing projects and projects nearing

See Oil Sands Symposium Presentation, supra note 3 at 12.

Government of Alberta, "Energy Prices," online: Alberta Economic Dashboard <economicdashboard. albertacanada.com/EnergyPrice $>$. The WTI/WCS price differential is partly due to the quality discount for Alberta heavy oil, and partly due to the geographic discount, meaning the discount that results from the shortage of capacity in export pipelines for Alberta oil. In other words, the price of heavy oil generally is lower than the price of light oil, and much of Alberta oil is trading at lower prices because it cannot reach tidewater from which to access overseas markets: Leach \& Smith, supra note 5. Canada West Report, supra note 7 at 6.

See e.g. Chen Aizhu, "Update 1 - China's oil demand to grow 3 pct in 2015-CNPC research" Reuters (28 January 2015), online: <af.reuters.com/article/energyOilNews/idAFL4N0V63LM20150128>. Crude Oil Forecast, supra note 2 at 11.

Canada West Report, supra note 7 at 2.

Ibid.

See e.g. "Enbridge's Line 9 pipeline reversal plan not OK'd by Montreal," CBC News (12 September 2014), online: <www.cbc.ca/news/canada/montreal/enbridge-s-line-9-pipeline-reversal-plan-not-ok-dby-montreal-1.2764660>; "Vancouver to take Trans Mountain pipeline challenges to Federal Court," Financial Post (23 August 2014), online: <business.financialpost.com/news/energy/vancouver-to-taketrans-mountain-pipeline-challenge-to-federal-court>.

Canada West Report, supra note 7 at 2.

Budget 2015, supra note 8. See also e.g. "The Economist explains: Why the oil price is falling" The Economist (8 December 2014), online: <www.economist.com/blogs/economist-explains/2014/12/ economist-explains-4>.

See e.g. Yadullah Hussain, “Almost \$60-billion in Canadian projects in peril as 'collapse' in oil investment echoes the dark days of 1999," Financial Post (2 January 2015), online: <business. financialpost.com/news/energy/almost-60-billion-in-canadian-projects-in-peril-as-collapse-in-oilinvestment-echoes-the-dark-days-of-1999>. Ibid. 
completion are expected to continue to expand in the next few years because producers will have significant sunk costs in projects. ${ }^{26}$ This will be the case as long as the price of oil stays high enough to cover the marginal costs, including pumping, transportation, and marketing. ${ }^{27}$ By contrast, conventional oil investments are short term in nature; conventional oil drilling activity is expected to decline substantially in $2016 .^{28}$

\section{B. SHIPPING OF OIL BY RAIL}

As a result of constrained oil pipeline capacity, the amount of oil shipped by rail has grown in recent years, although it is still only a fraction of the total amount of crude oil shipped out of the WCSB. There are some short-term advantages to transporting crude oil by rail. Rail is a more flexible option than pipelines and can quickly adapt to changing markets. ${ }^{29}$ In addition, transportation of crude oil by rail has not, to date, drawn the significant public opposition to crude oil transportation experienced by proposed pipelines in Canada and the US. However, there are safety concerns regarding the shipping of crude oil by rail. In addition, the cost of shipping by rail is roughly double or triple the cost of shipping by pipeline. ${ }^{30}$ With the current low price of oil, oil producers are seeking to cut costs, including transportation costs. Rail is now a less attractive option, and the need for increased export pipeline capacity is heightened. ${ }^{31}$

\section{OIl Pipelines as Common CARriers}

\section{A. The Nature of Common Carriers}

NEB-regulated oil pipelines have traditionally been described as "common carriers." 32 This means that they are required to transport all oil offered to them, unless the NEB grants an exemption. Section 71(1) of the NEBA is the legislative provision that describes the common carrier obligation for oil pipeline companies, although the words "common carrier" do not appear in this section or elsewhere in the NEBA. The section states:

Subject to such exemptions, conditions or regulations as the Board may prescribe, a company operating a pipeline for the transmission of oil shall, according to its powers, without delay and with due care and diligence, receive, transport and deliver all oil offered for transmission by means of its pipeline. ${ }^{33}$

\footnotetext{
26 "Marginal Costs of Oil Prodution" (12 December 2014), EclectEcon (blog), online: <www.eclectecon. net/2014/12/marginal-costs-of-oil-production.html>.

Ibid.

Crude Oil Forecast, supra note 2 at ii.

Canada West Report, supra note 7 at 18-20.

National Energy Board, Canadian Pipeline Transportation System: Energy Market Assessment, (Calgary: NEB, April 2014) at 7, online: <https://www.neb-one.gc.ca/nrg/ntgrtd/trnsprttn/2014/2014 trnsprttnssssmnt-eng.pdf $>$ [Transportation Report].

For more information on transportation of crude oil by rail, see generally Crude Oil Forecast, supra note 2 at 32 .

32 The NEB has noted that section 71(1) of the National Energy Board Act, RSC 1985, c N-7 [NEBA] "most closely relates to the common law duties of a common carrier pipeline" [footnote omitted]: Interprovincial Pipe Line Inc (December 1997), OH-2-97 at 49, online: NEB < https://docs.nebone.gc.ca/ll-eng/llisapi.dll? func=1lworkspace $>$ [Interprovincial Pipe Line]. NEBA, ibid, s 71(1).
} 
Economists Robert Mansell and Jeffrey Church suggest that a common carrier pipeline is "created by government edict and it, by definition, requires regulation." ${ }^{34}$ They suggest that on a common carrier pipeline, "when transmission capacity is insufficient, available capacity must be rationed on a pro rata basis across all customers, usually on the basis of their nominated shipping volumes." 35

A shipper may also apply for an order pursuant to section 71(3) of the NEBA requiring a pipeline company to provide existing or new facilities needed to receive, transport, and deliver hydrocarbons, provided that such an order will not place an undue burden on the pipeline company. Specifically, section 71(3) states:

The Board may, if it considers it necessary or desirable to do so in the public interest, require a company operating a pipeline for the transmission of hydrocarbons, or for the transmission of any other commodity authorized by a certificate issued under Part III, to provide adequate and suitable facilities for

(a) the receiving, transmission and delivering of the hydrocarbons or other commodity offered for transmission by means of its pipeline,

(b) the storage of the hydrocarbons or other commodity, and

(c) the junction of its pipeline with other facilities for the transmission of the hydrocarbons or other commodity,

if the Board finds that no undue burden will be placed on the company by requiring the company to do so. ${ }^{36}$

The detailed research performed for this paper revealed only one mention of section 71(3) in the context of oil pipelines: the Trans-Northern. ${ }^{37}$

The NEB has the following definition of "common carrier" in its online dictionary: "A pipeline company that is obligated to ship all product offered to it for transmission, without contract and usually by monthly nominations. In the event that capacity is not available to meet all requests, services are prorated amongst users." 38 This definition is consistent with the remarks of Mansell and Church, but it appears to be a historical definition. It does not reflect current NEB practice, which allows shippers and pipeline companies to enter into contracts for firm service provided that certain criteria are met, as will be discussed below.

By contrast, NEB-regulated natural gas pipelines are generally described as "contract carriers." Mansell and Church define a contract carrier as a pipeline that "provide[s] transmission service for gas owned by others according to a private contract between the

Robert L Mansell \& Jeffrey R Church, Traditional and Incentive Regulation: Applications to Natural Gas Pipelines in Canada (Toronto: Van Horne Institute for International Transportation and Regulatory Affairs, 1995) at 20.

Ibid.

NEBA, supra note 32, s 71(3).

Trans-Northern Pipelines Inc (November 2000), MH-3-2000 at 5, online: NEB <https://docs.neb-one.gc. ca/ll-eng/llisapi.dll? func $=1$ lworkspace $>$ [Trans-Northern] .

38 National Energy Board, "Pipeline Tolls and Tariffs: A Compendium of Terms," online: <www.nebone.gc.ca/bts/whwr/2007pplntllstrffscmpndmtrms-eng.html>. 
pipeline company and the shipper., ${ }^{39}$ Contract carriers are not generally required to ship products from all parties. The NEB regulation of access to natural gas pipelines will be discussed in a subsequent article.

\section{B. Common Carriage Obligation SubJect TO REASONABLENESS TEST}

The leading NEB decision on the nature of the common carriage obligation is PanCanadian. ${ }^{40}$ In this proceeding, PanCanadian Petroleum Limited (PanCanadian) applied for an order requiring Interprovincial Pipe Line Inc. (IPL) to transport natural gas liquids (NGL) for PanCanadian from Kerrobert, Saskatchewan, to markets in eastern Canada and the US. The composition of the NGL was such that it fit under the definition of "oil" under section 2 of the NEBA, so the pipeline was an oil pipeline subject to the common carriage obligation under section 71(1).

Prior to adding another shipper, IPL required consent from existing shippers based on IPL's operating procedures. Amoco, the only existing NGL shipper on IPL, objected to the provision of service to PanCanadian because PanCanadian had requested that its NGL be commingled with Amoco's product.

The Board held that IPL, in not providing public access for NGL to be transported on its pipeline, had failed to comply with its common carrier obligations. The NEB stated that the common carriage obligations of an oil pipeline are relative, rather than absolute obligations, which are tempered by a test of reasonableness. Specifically, the NEB stated as follows:

[C]ompliance with the common carrier provisions is determined by a test of reasonableness, which is a relative concept. Section 71 of the NEB Act is consistent with [the] common law approach because it permits the Board to tailor the statutory obligations of both oil and gas pipelines to fit any unique circumstances which may exist. Thus, the Board can increase or decrease the statutory common carrier obligations of an oil, gas or commodity pipeline in respect of their carriage of oil, gas or another commodity. ${ }^{41}$

The NEB also noted that no provision in a pipeline company's tariffs could detract from the common carrier obligations imposed by the NEBA.

On the concept of reasonableness, the NEB cited Patchett \& Sons Ltd v. Pacific Great Eastern Railway Co. in which the Supreme Court of Canada held that a railway company's common carrier obligations to provide reasonable facilities were limited by the concept of

$39 \quad$ Mansell \& Church, supra note 34 at 20.

$40 \quad$ PanCanadian Petroleum Limited (February 1997), MH-4-96, online: NEB <https://docs.neb-one.gc. ca/ll-eng/llisapi.dll? func=llworkspace $>$ [PanCanadian]. The NEB has cited PanCanadian in numerous other decisions, including: see e.g. Novagas Clearinghouse Pipelines Ltd (May 1997), OH-2-96 at 12, online: NEB <https://docs.neb-one.gc.ca/ll-eng/llisapi.dll?func=llworkspace>; Federated Pipe Lines (Northern) Ltd (April 1997), OH-3-96, at 13, online: NEB < https://docs.neb-one.gc.ca/1l-eng/llisapi.dll? func=llworkspace $>$ [Federated]; Enbridge Southern Lights LP (1 February 2008), OH-3-2007 at 56, online: NEB $<$ https://docs.neb-one.gc.ca/ll-eng/llisapi.dll?func=llworkspace $>$ at 56 [Enbridge Southern Lights].

$41 \quad$ PanCanadian, ibid at 11. 
reasonable service and that common carriers "cannot be compelled to bankrupt themselves by doing more than what they have embraced within their public profession." 42

\section{Why Were Oil Pipelines Originally DESIGNATED AS COMMON CARRIERS?}

The first Canadian long-distance oil pipelines were constructed in the $1950 \mathrm{~s} .{ }^{43}$ Oil pipelines may originally have been designated as common carriers because of the properties of oil as a substance and because of the structure of oil markets at that time.

Crude oil is not generally usable in the form in which it is produced from a well in the oil patch. It must be transported to a refinery where it is refined into consumer products such as petroleum, naphtha, gasoline, diesel fuel, asphalt base, heating oil, kerosene, and liquefied petroleum gas. ${ }^{44}$ There are many different grades of crude oil, ranging from light oil to heavy oil and bitumen. While light oil is the most valuable, bitumen is dense and highly viscous, and must be diluted with condensate in order to be transported in pipelines. Different grades of crude oil must be transported in separate batches because mixing a higher grade of oil with a lower grade of oil would lower the value of the higher grade of oil.

Crude oil is a liquid at ambient temperature. As a result, it is relatively easy and inexpensive to build storage facilities (sometimes known as tank farms or oil terminals) for crude oil at both the upstream and downstream ends of transmission pipelines. These storage facilities can be used to smooth out or ensure regular deliveries to customers.

Crude oil in North America has generally been purchased and sold on a short-term basis, typically month-to-month, in "spot markets." ${ }^{45}$ Generally, individual end-users do not need to have long-term contracts on transmission pipelines in order to have security of supply because there are alternative means of transportation for oil. ${ }^{46}$ Oil can be delivered by ocean tankers and barges from around the world, other oil pipelines, petroleum product pipelines, rail, or truck.

Similarly, Canadian oil pipeline companies traditionally allocated capacity on a short-term or month-to-month basis. Every month, shippers would nominate the volume of crude oil they wished to ship on a given pipeline. As shippers were buying and selling crude oil in spot markets on a monthly basis, this arrangement worked well for them. Oil pipeline companies have often been vertically integrated. In other words, oil pipelines have often been

\footnotetext{
42 Ibid, citing AL Patchett \& Sons Ltd v Pacific Great Eastern Railway Company, [1959] SCR 271 at 275.

43 Canadian Energy Pipeline Association, "History of Pipelines," online <www.cepa.com/aboutpipelines/history-of-pipelines $>$.

44 Thomas O Miesner \& William L Leffler, Oil and Gas Pipelines in Nontechnical Language (Tulsa: PennWell, 2006) at 6-7.

45 An NEB publication contains this definition of "spot market" as a "[m]arket where people buy and sell actual commodities or financial instruments for instant delivery. The spot market contrasts with the futures market, in which contracts are completed at a specified time in the future": National Energy Board, Canadian Electricity: Trends and Issues (Calgary: NEB, May 2001) at 64, online: < publications. gc.ca/collections/Collection/NE23-94-2001E.pdf>. Mansell \& Church, supra note 34 at 21.
} 
constructed and owned by oil producers that also refine their own oil. ${ }^{47}$ Clearly, vertically integrated pipeline companies have no need for long term transportation contracts.

Until 1997, all long-distance oil pipelines in Canada were truly common carriers. Historically, shippers did not need the certainty provided by long-term firm contracts given the numerous supply and transportation alternatives available to them and relatively easy access to storage. Further, long-term contracts would not have fit well with the spot market for oil or with the inability to commingle batches of crude oil.

Today, the majority of capacity in the oil pipeline systems in Canada is subject to longterm firm contracts. Since 1997, when the Express Pipeline was approved, competition among oil pipelines has been growing. In addition, there have been dramatic changes in oil and gas markets since $2007 .{ }^{48}$ Due to technological advances in the production of oil and gas, it is now possible to economically produce large volumes of oil and gas from tight and shale formations in Canada and the US. ${ }^{49}$ Also, oil sands production has increased. Rapid growth in WCSB oil sands and US tight oil production has resulted in a surplus of oil in the middle of North America since 2011. ${ }^{50}$ As a result, oil export pipeline capacity is tight ${ }^{51}$ - for example, both Enbridge and Trans Mountain pipelines have had to significantly apportion volumes shipped. ${ }^{52}$

\section{Major Long-Distance Oil Pipelines Today}

Today, there are four major oil pipeline systems that transport oil production out of the WCSB: Trans Mountain, Express (now Spectra Energy Express-Platte), the Keystone Pipeline System, and the Enbridge Mainline. In three of these four major pipeline systems, the majority of capacity is now subject to long-term firm contracts with shippers, also known as Transportation Service Agreements (TSAs). Eighty percent of the existing Trans Mountain pipeline is subject to long-term firm contracts, with this percentage remaining constant in the proposed expansion. ${ }^{53}$ Eighty-five percent of the Express pipeline is subject to long-term firm contracts. ${ }^{54}$ Up to 88 percent of the capacity of Keystone XL is subject to long-term firm contracts, and up to 94 percent of Keystone Base is subject to long-term firm contracts. ${ }^{55}$ Enbridge proposes to have 95 percent of the Northern Gateway Pipeline subject to firm contracts. By contrast, the Enbridge Mainline remains entirely a common carrier pipeline, with no long-term contracts.

\footnotetext{
$47 \quad$ Ibid.

48 Transportation Report, supra note 30 at 1.

Ibid.

Ibid at 5 .

Ibid.

Ibid. The NEB Transportation Report explains apportionment as follows: "In a given month, if shippers nominate more volume than the pipeline can transport then each shipper's nominated volume is apportioned or reduced by the same percentage" (ibid).

53 Trans Mountain Pipeline ULC (16 May 2013), RH-001-2012, online: NEB <https://docs.neb-one.gc.ca/ 1l-eng/llisapi.dll?func=llworkspace $>$ [Trans Mountain Expansion].

${ }_{54}$ TransCanada Keystone Pipeline GP Ltd (March 2010), OH-1-2009, online: NEB < https://docs. nebone.gc.ca/ll-eng/llisapi.dll? func=llworkspace $>$ [Keystone XL].

55 TransCanada Keystone Pipeline GP Ltd (September 2007), OH-1-2007, online: NEB < https:// docs.nebone.gc.ca/ll-eng/llisapi.dll? func=llworkspace $>$ [Keystone Base].
} 


\section{A. Enbridge Pipelines}

\section{ENBRIDGE MAINLINE}

Enbridge is Canada's largest transporter of crude oil, delivering on average more than 2.2 million bpd of crude oil and liquids. ${ }^{56}$ The Enbridge Canadian mainline (formerly the Interprovincial Pipeline) commences in Edmonton, Alberta, and is made up of six pipelines exiting western Canada that transport natural gas liquids, synthetic crude oil, refined petroleum products, light crude oil, condensate, and heavy crude oil. ${ }^{57}$ The six lines interconnect with other Enbridge pipelines to serve destinations in central Canada including Montreal, Quebec, and destinations in the US including the Cushing Hub and Toledo. The Enbridge Mainline Pipeline System includes the Clipper Pipeline which runs from Hardisty, Alberta to Gretna, Manitoba, and south to Superior, Wisconsin, in the US. ${ }^{58}$ Enbridge intended to expand capacity in the Clipper Pipeline by 2015, but the US portion of the capacity expansion has been delayed pending issuance of a US presidential permit. ${ }^{59}$

After extensive negotiations with shippers, Enbridge entered into a Competitive Tolling Settlement Agreement (CTS) with shippers in 2011 for ten years. ${ }^{60}$ The tolls are set pursuant to the agreement in which the Enbridge mainline is no longer based on a cost of service toll methodology. Under the terms of the CTS, Enbridge stands to earn a greater return on equity if it accepts more risk with respect to volumes, capital, or other stated factors on a particular project. $^{61}$

Enbridge has received approval from the NEB, subject to certain conditions, to reverse (or re-reverse) the direction of flow in Line 9 from Sarnia, Ontario to Montreal, Quebec and to expand the capacity of the entire Line 9 to approximately $300,000 \mathrm{bpd} .{ }^{62}$ The Line 9 reversal will allow Enbridge to ship crude oil from western Canada to the Ontario market, an Ontario refinery, and Montreal refineries. ${ }^{63}$ Line 9 originally flowed from west to east, but in 1998 it was reversed to flow from east to west to receive oil from overseas. It now makes sense to re-reverse the flow of the line given the forecast for substantial growth in western Canadian light crude oil supply. ${ }^{64}$

Enbridge Inc, “Our Pipelines,” online: <www.enbridge.com/DeliveringEnergy/OurPipelines.aspx > . Transportation Report, supra note 30 at 14.

Enbridge Inc, “Alberta Clipper (Line 67) Capacity Expansion,” online: <www.enbridge.com/Mainline EnhancementProgram/Canada/Alberta-Clipper-Capacity-Expansion.aspx>.

Enbridge Inc, “Alberta Clipper (Line 67) Capacity Expansion Phase II," online: <www.enbridge.com/ MainlineEnhancementProgram/Canada/Alberta-Clipper-Capacity-Expansion-Phase-II.aspx >.

Enbridge Pipelines Inc, Competitive Toll Settlement (1 July 2011), online: <www.enbridge.com/ $\sim /$ media/www/Site\%20Documents/Delivering\%20Energy/Shippers/Appendix\%201\%20\%20 Competitive\%20Toll \%20Settlement\%20the\%20CTS.pdf?la=en>.

61 Ibid at para 16.7 , Appendix 1.

62 Transportation Report, supra note 30 at 15; National Energy Board, News Release, "NEB approves Line 9B Project with conditions" (6 March 2014), online: <www.neb-one.gc.ca/bts/nws/nr/archive/2014/ nr10-eng.html >; Enbridge Pipelines Inc. Line 9 Reversal Phase I Project (27 July 2012), OH-005-2011 (Letter Decision), online: NEB <https://docs.neb-one.gc.ca/ll-eng/llisapi.dll?func=llworkspace> [Enbridge Letter Decision]; Canada West Report, supra note 7 at 17. It will provide lower-priced Canadian crude oil to Imperial Oil's Nanticoke refinery near Port Dover, Ontario so that Imperial does not have to rely on higher-priced offshore crude oil: see Enbridge Letter Decision, ibid at 4 (position of Imperial Oil).

Canada West Report, ibid at 17.

Enbridge Letter Decision, supra note 62 at 3 (position of Enbridge). 


\section{PROPOSED ENBRIDGE NoRTHERN GATEWAy PIPELINE}

The proposed Northern Gateway pipeline (Northern Gateway) would be capable of transporting an average of 525,000 bpd of crude oil from Bruderheim in northern Alberta to the northwest coast of British Columbia at Kitimat. ${ }^{65}$ From Kitimat, the oil could be transported to overseas markets, particularly Asia, by tanker. Northern Gateway would transport bitumen diluted with condensate to allow it to flow freely in the pipeline, as well as other oil products. The project includes a parallel condensate pipeline which would transport the used condensate back to Alberta for re-use.

\section{B. Trans Mountain Pipeline}

The existing Kinder Morgan Trans Mountain pipeline transports crude oil and refined products from Edmonton, Alberta to Burnaby, British Columbia ${ }^{66}$ It is currently the only oil pipeline from Alberta directly to the west coast, ${ }^{67}$ and it provides access to Asian markets, as well as to other markets in the US and overseas through the Westridge marine terminal at Burnaby, British Columbia. ${ }^{68}$ In addition, Trans Mountain delivers oil products to marketing terminals and refineries in central British Columbia, and the Greater Vancouver area. It also connects to a US affiliate at Sumas, on the British Columbia-Washington State border, for delivery to refineries in the Puget Sound area in Washington State. Eighty percent of the capacity of the Trans Mountain pipeline is allocated through long-term firm contracts.

Kinder Morgan proposes to expand the Trans Mountain pipeline. The proposed expansion, if approved by the NEB, would create a twinned pipeline that would increase the nominal capacity of the existing pipeline by almost three times, from $300,000 \mathrm{bpd}$ to $890,000 \mathrm{bpd}{ }^{69}$ Both the City of Vancouver and the City of Burnaby are opposed to the proposed expansion based on environmental concerns. ${ }^{70}$ The NEB is scheduled to make its final recommendation to the Governor-in-Council regarding the project by 20 May $2016 .^{71}$

National Energy Board, Considerations: Report of the Joint Review Panel for the Enbridge Northern Gateway Project, vol 2 (Calgary: NEB, 2013) at 3, 5 [Considerations]. On 17 June 2014, the Governorin-Council approved the Northern Gateway Project, subject to the 209 conditions set out by the Joint Review Panel: see National Energy Board, "Decision Statement Issued under Section 54 of the Canadian Environmental Assessment Act, 2012 and Paragraph 104 (4) (b) of the Jobs, Growth and Long-term Prosperity Act," (17 June 2014) online, <gatewaypanel.review-examen.gc.ca/clfnsi/dcmnt/dcsnsttmnt-eng.html> ["Northern Gateway Decision Statement"]. Kinder Morgan, "Trans Mountain Pipeline System," online: <www.kindermorgan.com/pages/ business/canada/transmountain.aspx $>$.

Canada West Report, supra note 7 at 17.

Trans Mountain Expansion, supra note 53.

Trans Mountain Pipeline, "Proposed Expansion," online: <www.transmountain.com/proposedexpansion>.

70 Dene Moore, "Burnaby, Trans Mountain both looking for support in pipeline fight," Canadian Business (26 September 2014), online: <www.canadianbusiness.com/business-news/burnaby-trans-mountainboth-looking-for-support-in-pipeline-fight/>.

71 National Energy Board, "Trans Mountain Pipeline ULC - Trans Mountain Expansion," online: $<$ www.neb-one.gc.ca/pplctnflng/mjrpp/trnsmntnxpnsn/index-eng.html $>$. 


\section{SPECTRA Energy EXPRESS-Platte}

The Express Pipeline commenced operation in 1997. Express Pipeline was the first longdistance oil pipeline in Canada to have long-term firm contracts with its shippers for a majority of its capacity. ${ }^{72}$ The Express Pipeline has a capacity of approximately $280,000 \mathrm{bpd}$.

The Express Pipeline and the Platte pipeline are now owned by Spectra Energy ExpressPlatte. ${ }^{73}$ The Express Pipeline delivers Western Canadian crude oil from Hardisty, Alberta, to Casper, Wyoming, where it interconnects with the Platte Pipeline. The Platte Pipeline transports the crude oil to refineries in the Rocky Mountain and midwest regions of the US. ${ }^{74}$ The Express Pipeline and the Enbridge mainline both commence at Hardisty, Alberta, and they compete for crude oil supply from the $\mathrm{WCSB},{ }^{75}$ although they serve different markets.

\section{Keystone Pipeline System}

The Keystone Pipeline system can be described as four pipelines:

(1) Keystone Base is already operational and it runs from Hardisty, Alberta, to Steele City in Nebraska, and to Wood River and Patoka in Illinois. More than half of Keystone Base involved the conversion of existing under-utilized natural gas pipeline in Saskatchewan and Manitoba.

(2) The Cushing Expansion is already operational, running from Steele City to the Cushing Hub in Oklahoma.

(3) The Gulf Coast Project, from Cushing to Nederland and Houston, Texas (on the Gulf Coast) commenced operations in January $2014 .{ }^{76}$ With the completion of the link to the Gulf Coast, this is the first time that supply from the WCSB has been directly connected to the US Gulf Coast, which, according to Keystone, is a "large, highly desirable, and virtually untapped market.",77

(4) The Keystone XL Pipeline would extend diagonally from Hardisty, Alberta, to Steele City, Nebraska. The NEB has approved the Canadian portion of Keystone XL. ${ }^{78}$ The portion of the Keystone XL Pipeline from the Canadian border to Steele City, Nebraska, was rejected by the Obama administration in the US in November 2015. President Barack Obama stated that the pipeline would not make a meaningful long-

National Energy Board, Canadian Pipeline Transportation System: Transportation Assessment (Calgary: NEB, 2009) at 12, online: <https://www.neb-one.gc.ca/nrg/ntgrtd/trnsprttn/archive/2009/ 2009 trnsprttnssssmnt-eng.pdf $>$ [Transportation Assessment].

73 Spectra Energy Corp, "Express Pipeline," online: <www.spectraenergy.com/Operations/Crude-OilTransportation/Express-Pipeline/>; Spectra Energy Corp, "Platte Pipeline," online: <www.spectra energy.com/Operations/Crude-Oil-Transportation/Platte-Pipeline/> [“Platte”].

"Platte," ibid.

Express Pipeline Ltd Facilities and Toll Methodology (June 1996), OH-1-95, online: NEB <https://docs. neb-one.gc.ca/ll-eng/llisapi.dll?func=llworkspace $>$ [Express Pipeline].

According to an industry representative, the Gulf Coast Project was originally named as part of the Keystone XL Project but this was later renamed after the difficulties in getting the entire Keystone XL project approved in the US became apparent.

$77 \quad$ Keystone XL, supra note 54 at 28.

Ibid at 49. 
term contribution to the US economy. TransCanada has filed two lawsuits, one against the Obama administration ${ }^{79}$ and one under the North American Free Trade Agreement. ${ }^{80}$ Environmental groups have expressed concerns about the potential negative impacts of the Keystone XL Pipeline and the fact that it will transport oil from the Alberta oil sands.

\section{E. Proposed Energy East Project}

TransCanada filed a combined facilities and tolling methodology application for the Energy East Pipeline with the NEB on 30 October $2014 .^{81}$ The NEB is currently reviewing amendments filed by TransCanada in December 2015. ${ }^{82}$ The Energy East Pipeline would carry 1.1 million barrels of crude oil per day from Hardisty, Alberta, and Saskatchewan to existing refineries in Montreal, near Quebec City, and Saint John, New Brunswick. ${ }^{83}$ Marine facilities would be built in Quebec City and Saint John to allow marine tankers to be loaded with crude for shipment to export markets. ${ }^{84}$ The project includes the conversion of portions of the existing underutilized TransCanada mainline from natural gas service to oil service and the construction of new facilities. Currently the refineries in eastern Canada receive oil shipped from overseas, which is expensive.$^{85}$ This project, if approved, will provide Canadian refineries with a reliable source of domestic crude oil. It is anticipated to be in service in $2020 .^{86}$

TransCanada has estimated that tolls on Energy East will be competitive with west coast access pipelines, presumably because TransCanada would convert some existing gas facilities to oil service. The pipeline would provide an alternative transportation option for WCSB crude oil producers to access eastern Canadian, US, and other international markets. ${ }^{87}$ It should also lessen the price discount on Alberta oil. Environmental groups and First Nations have expressed concerns about Energy East. ${ }^{88}$

"Keystone XL rejection leads TransCanada to sue Obama administration" CBC News (6 January 2016) online: $<$ http://www.cbc.ca/news/canada/calgary/transcanada-lawsuit-keystone-xl-pipeline-1.3392446>. "Barack Obama rejects Keystone XL pipeline citing "national interest," CBC News (6 November 2015) online: <www.cbc.ca/news/business/keystone-xl-pipeline-obama-1.3307440>. National Energy Board, "Energy East Project," online: <www.one-neb.gc.ca/pplctnflng/mjrpp/nrgyst/ index-eng.html $>$ [NEB, "Energy East]; National Energy Board, Media Release, "National Energy Board Receives Application for Energy East" (30 October 2014), online: <www.neb-one.gc.ca/bts/nws/nr/ 2014/mddvsrymvnrgst-eng.html >.

82 NEB, "Energy East," ibid.

83 TransCanada Pipelines Limited, "Energy East Pipeline Project," online: <www.transcanada.com/energyeast-pipeline. html> [TransCanada, "Energy East"]. Ibid.

TransCanada Pipelines Limited, "Need for a Pipeline,” online: <www.energyeastpipeline.com/home/ need-for-a-pipeline/>.

$86 \quad$ Robert Tuttle, "NDP victory delays day of reckoning for pipelines," Calgary Herald (7 May 2015) B4.

87 Deloitte \& Touche LLP, Energy East: The economic benefits of TransCanada's Canadian Mainline conversion project, online: <www.energyeastpipeline.com/wp-content/uploads/2013/09/Energy-EastDeloitte-Economic-Benefits-Report.pdf $>$ [Deloitte Report].

88 Shawn McCarthy, "Environmental, First Nations groups question the safety of Energy East pipeline plan,” The Globe and Mail (9 August 2013), online: <www.theglobeandmail.com/news/politics/environ mental-first-nations-groups-question-pipeline-plan/article13701985/>.
} 


\section{F. The DeVelopment of PiPe-ON-Pipe COMPETITION FOR OIL PIPELINES}

In the 1950s, when Interprovincial Pipeline and Trans Mountain Pipeline System commenced operations, neither pipeline had any significant competition in their respective destination markets. At that time, Interprovincial Pipeline was the only long-distance oil pipeline transporting oil from Alberta to eastern North America, and Trans Mountain was the only oil pipeline transporting oil from Alberta to the west coast of Canada.

As oil and natural gas export markets have grown, more export pipeline capacity has been constructed, and as a result, pipe-on-pipe competition has developed for both oil and natural gas pipelines. The transportation of oil by rail has also grown as an alternative to pipeline transportation.

Today, four major pipelines compete for crude oil supply from the WCSB, although they serve different destination markets: Express Pipeline, Keystone Base, the Enbridge mainline, and Trans Mountain. Based on forecasted WCSB crude oil production, there will be sufficient crude oil volumes for all of these pipelines, as well as the proposed Keystone XL, Trans Mountain Expansion, Northern Gateway, and Energy East pipeline projects until at least $2021 .^{89}$

Northern Gateway, if constructed, will compete directly with Trans Mountain for access to Asian markets. Asian demand for crude oil is forecast to be far larger than the capacity of both an expanded Trans Mountain and Northern Gateway together. ${ }^{90}$

Energy East, if approved, would compete in part with the Enbridge mainline once the Line 9 reversal is operational. Both Energy East and Enbridge Line 9 would serve Montreal refineries, as well as other destination markets. ${ }^{91}$

If actual oil sands production falls short of forecasted production in the coming years so that there is excess takeaway pipeline capacity from the WCSB, Northern Gateway and Enbridge mainline may be the pipelines to suffer volume risk, as these two pipelines do not currently have firm contracts with shippers. Express, Keystone Base, Trans Mountain, and Energy East all have firm contracts for the majority of the capacity of the pipelines.

\section{ECONOMIC THEORY: Why Should the NeB Regulate Access to Oil Pipelines?}

Western societies generally consider that competitive market economies produce the most efficient outcomes from an economic perspective. ${ }^{2}$ However, in natural monopolies,

Millington \& Rozhon, supra note 3 at 13. See also Deloitte Report, supra note 87.

See Canada West Report, supra note 7 at 2.

TransCanada, "Energy East," supra note 83; Canada West Report, ibid at 17.

Alfred E Kahn, The Economics of Regulation: Principles and Institutions, vol 1 (Cambridge, Mass: MIT

Press, 1993) at 17 [Kahn, vol 1]. 
economic theory states that competition is infeasible. Crude oil ${ }^{93}$ and natural gas ${ }^{94}$ transmission pipelines can be considered to be natural monopolies, at least when the first oil or natural gas pipeline is built in a given market. This is because the incremental cost to an incumbent pipeline owner of shipping one more unit of product in the pipeline is minimal compared to the capital cost that would be faced by a new market entrant wishing to construct another pipeline. This is true until the oil or gas transmission market grows to the point where the incumbent pipeline reaches full capacity.

Economic theory states that natural monopolies, including crude oil and natural gas transmission pipelines, should be regulated. Without regulation, the pipeline owner could exact monopolistic or excessively high rates from customers.

\section{A. Competition AND Natural Monopolies}

Alfred Kahn described the benefits of competition thus:

Competition will weed out the inefficient and concentrate production in the efficient; it will determine, by the objective test of market survival, who should be permitted to produce; it will force producers to be progressive and to offer customers the services they want and for which they are willing to pay; it will assure the allocation of labor and other inputs into the lines of production in which they will make the maximum contribution to total output. ${ }^{95}$

According to Kahn, certain industries are natural monopolies because either the technology of the industry or the character of the service provided is such that "the customer can be served at least cost or greatest net benefit only by a single firm ... or by a limited number" of firms. ${ }^{96}$ Kahn states that "[a] 'natural monopoly' is an industry in which the economies of scale - that is, the tendency for average costs to decrease the larger the producing firm - are continuous up to the point that one company supplies the entire demand." 97 As a result, competition will only result in higher social costs and is undesirable. $^{98}$

Alan J MacFadyen \& G Campbell Watkins, Petropolitics: Petroleum Markets and Regulations, Alberta as an Illustrative History (Calgary: University of Calgary Press, 2014) at 31. In Trans Mountain Expansion, supra note 53, the NEB stated: "[c]rude oil pipelines like Trans Mountain tend to be natural monopolies and, as a result, highly concentrated markets are to be expected" (ibid at 18). Nikol J Schultz, "Light-Handed Regulation" (1999) 37:2 Alta L Rev 387 at 394. For a discussion on monopolies, see Stanislaw H Wellisz, "Regulation of Natural Gas Pipeline Companies: An Economic Analysis" (1963) 71:1 J Political Economy 30 at 36.

$95 \quad$ Kahn, vol 1, supra note 92 at 18.

96 Alfred E Kahn, The Economics of Regulation: Principles and Institutions, vol 2 (Cambridge, Mass: MIT Press, 1993) at 2 [Kahn, vol 2]. In a similar vein, Richard Posner defines a natural monopoly as "a market whose entire demand can be met at lowest cost by a single firm. This implies that before a firm can begin to do business it must sink large sums in a plant that is large enough or can readily be expanded to serve the entire market. Once the heavy initial fixed or overhead expenses are incurred, the cost of serving a particular customer is relatively slight": Richard A Posner, "Natural Monopoly and Its Regulation" (1969) 21 Stan L Rev 548 at 570.

$97 \quad$ Kahn, vol 1, supra note 92 at 123-24.

98 James C Bonbright, Albert L Danielsen \& David R Kamerschen, Principles of Public Utility Rates, 2nd ed (Arlington: Public Utilities Reports, Inc, 1988) at 8. 


\section{B. Regulation AS A Substitute for CoMpetition}

In a natural monopoly environment, regulation provides a surrogate for competition. ${ }^{99}$ According to Kahn, regulation should be aimed at producing the same results as competition: "the single most widely accepted rule for the governance of the regulated industries is regulate them in such a way as to produce the same results as would be produced by effective competition, if it were feasible." 100

Kahn makes the point that regulation tends to spread and beget more regulation. ${ }^{101}$ Regulation can cause unforeseen consequences which in turn need to be regulated. Thus, the goal in regulating public utilities should always be to create as little regulation as is necessary to mimic the results a properly functioning competitive market would provide. While neither regulation nor competition is a perfect solution, the goal of public utility regulation should be to find "the best possible mix of inevitably imperfect regulation and inevitably imperfect competition." 102

\section{Regulation to Provide Open Access to Transmission Pipelines}

One of the major goals of regulation of transmission pipelines is to establish open access to pipelines for third parties. ${ }^{103}$ Unlike transmission and distribution, oil and gas production and supply markets can be competitive and are not considered to be natural monopolies. ${ }^{104}$ Open access to transmission is fundamental to the establishment of competitive oil and natural gas production and supply markets. ${ }^{105}$ Without regulation, open access to transmission would likely never happen. In the absence of regulation, a dominant owner of transmission or distribution pipelines can quickly become the principal barrier to entry of new market players in supply markets. ${ }^{106}$ The transmission pipeline owner may control access by extracting monopoly rents from customers, which could theoretically be any price up to the cost of building an alternative system (or switching to another fuel). ${ }^{107}$

Peter Duncanson Cameron, Competition in Energy Markets: Law and Regulation in the European Union, 2nd ed (Oxford: Oxford University Press, 2007) at para 1.76.

Kahn, vol 1, supra note 92 at 17.

Kahn, vol 2, supra note 96 at 28.

Kahn, vol 1, supra note 92 at xxxvii.

Peter Cameron states that "[t]he core aim of most market reform programmes is the creation of enforceable rights of access for third parties to the transmission and distribution networks": Cameron, supra note 99 at 30 .

Bartłomiej Nowak, "Independence of the Polish Energy Regulator after the Third Energy Package: Chosen Aspects" in Robert Zajdler, ed, EU Energy Law: Constraints with the Implementation of the Third Liberalisation Package (Newcastle upon Tyne: Cambridge Scholars, 2012) 129 at 132.

See e.g. Bartlomiej Nowak, "Equal Access to the Energy Infrastructure as a Precondition to Promote Competition in the Energy Market: The Case of European Union" (2010) 38 Energy Policy 3691 at 3699 [Nowak, "Equal Access"]. Nowak states that open access to electricity and natural gas transmission and distribution is essential for the development of competitive energy markets in the European Union. Cameron, supra note 99 at 30.

Ibid at 32 . 


\section{OBJECTIVES FOR REGULATION OF OIL AND Natural Gas Pipelines}

Based on the foregoing discussion, the following objectives for regulation of oil and natural gas pipelines can be established:

1. The goal of regulation of natural monopolies should be "to produce the same results as would be produced by effective competition, if it were feasible."108

2. In order to encourage the development of competitive oil and gas commodity markets, the regulator ought to establish open access to oil and natural gas transmission pipelines. $^{109}$

3. In developed oil and natural gas transmission networks, competition may exist; therefore the regulator ought not to prevent entry of new firms. ${ }^{110}$

The approach of the NEB will be assessed against these objectives.

\section{The NEB: Policy AND DeCISIONS Regarding ACCess to Major OIL PiPelines}

\section{A. NEB Policy Statements: COMPETITIVE OIL AND GAS TransPortation MARKETS}

The NEB has noted both in the context of oil pipelines ${ }^{111}$ and natural gas pipelines ${ }^{112}$ that pipelines tend to be natural monopolies. The approach of the NEB is to encourage competition in pipelines by encouraging the adoption of competitive tolls ${ }^{113}$ and the construction or expansion of pipelines that will open up new markets for Canadian producers. ${ }^{114}$ Former Chair and CEO of the National Energy Board, Gaétan Caron, emphasized the importance of competitive markets in a speech he gave at the 2013 Canadian Energy Summit, stating:

[T] he NEB's approach to regulation continues to be premised on the belief that markets work. The Board can step in if, for some reason, markets are not functioning properly, but we believe that well-functioning, competitive markets efficiently balance supply and demand through adjustments in prices. They also lead to competitive, innovative, and robust energy systems. ${ }^{115}$

Kahn, vol 1, supra note 92 at 17.

See e.g. Nowak, "Equal Access," supra note 105 at 3699.

Kahn, vol 2, supra note 96 at 153 . For a more general discussion see Posner, supra note 96.

In Trans Mountain Expansion, supra note 53, the NEB stated: "crude oil pipelines like Trans Mountain tend to be natural monopolies and, as a result, highly concentrated markets are to be expected" (ibid at 18).

See Mackenzie Gas Project Reasons for Decision (2010) GH-1-2004, vol 2, online: NEB <https://docs. neb-one.gc.ca/ll-eng/llisapi.dll?func=llworkspace $>$ (regarding the Mackenzie Valley Pipeline the NEB stated that pipeline markets are "often natural monopolies" at 171).

See e.g. Express Pipeline, supra note 75; Keystone XL, supra note 54 at 30.

Trans Mountain Expansion, supra note 53.

Gaétan Caron, "National Energy Board Update" (Speech delivered at the Canadian Energy Summit, 8 November 2013), online: NEB <https://docs.neb-one.gc.ca/ll-eng/llisapi.dll?func=llworkspace> [emphasis in original]. 
One of the NEB's goals as set out in its Strategic Plan is that "Canadians benefit from efficient energy infrastructure and markets." "I16 In order to determine whether NEB-regulated pipelines are succeeding in meeting this goal, the NEB periodically assesses "the economic functioning of the pipeline transportation system. ${ }^{117}$ The NEB states that "[a]n efficient pipeline transportation system effectively responds to changing market conditions." 118 The NEB recognized in Keystone Base that "the market for oil transportation has evolved and will continue to evolve to embrace commercial arrangements better suited to meet the needs of market participants."119 As a result, "under certain conditions and circumstances," 120 it is acceptable for common carriage oil pipelines to have firm contractual commitments to capacity. In most major oil pipelines in Canada today, the majority of capacity is subject to firm transportation agreements, with the residual amount of capacity being available for uncommitted volumes.

Despite supporting the operation of functioning markets, the NEB retains its discretion to regulate pipelines under its jurisdiction where regulation is necessary to the public interest. When a shipper or other directly affected party files a complaint with the NEB regarding treatment by a pipeline company, the NEB will typically hold a hearing to deal with the complaint. $^{121}$

\section{B. DEREgulation AND OPEN ACCESS TO Oil and Gas Transmission Pipelines}

The establishment of open access to both oil and natural gas pipelines has been a key objective of the NEB at least since 1986, when the prices of crude oil and natural gas were deregulated. Deregulation occurred as a result of two agreements signed by the governments of Canada, Alberta, British Columbia, and Saskatchewan in 1985: the "Western Accord of 28 March 1985 on Energy Pricing and Taxation" (Western Accord) and the "Agreement on Natural Gas Markets and Prices on 31 October 1985" (Halloween Agreement). ${ }^{122}$ These agreements took effect on 1 November 1986, the year after they were signed. ${ }^{123}$ Continued open access to both crude oil and natural gas pipelines was key in order to ensure successful oil and gas commodity markets. If producers could not access pipelines, their ability to reach markets would be limited. This issue was more significant for natural gas producers than for oil producers given that oil producers had other transportation options, including rail, trucks, and tankers, as discussed above.

Transportation Assessment, supra note 72 at viii.

Transportation Report, supra note 30 at 1 . The NEB also lists factors considered in determining whether a pipeline transportation system is well-functioning: ibid.

Ibid.

Keystone Base, supra note 55 at 20.

Ibid.

See NEBA, supra note 32, s 56(2).

Keith F Miller, "Energy Regulation and the Role of the Market" (1999) 37:2 Alta L Rev 419 at 420.

Alexander J Black, "Canadian Natural Gas Deregulation: Contractual Impediments and Discriminatory Consequences" (1989) 7:1 J Energy \& Natural Resources L 42 at 50. 
The NEB states:

The Board requires that pipeline companies operate according to the principle of "open access". This means that all parties must have access to transportation on a non-discriminatory basis.... In addition, tolls for services provided under similar circumstances and conditions with respect to all traffic of the same description, carried over the same route, must be the same for all customers. ${ }^{124}$

The earliest and most frequently cited NEB decision on open access is TransCanada $\mathrm{GH}$ 2-87, a natural gas decision wherein the NEB stated:

The Board ... considers it essential that all terms and conditions of access to a pipeline be clearly reflected in the tariff in order to ensure that there are no undue service restrictions imposed by pipeline companies involved in the marketing or producing sectors of the natural gas sector. In the Board's view, prospective shippers are entitled to know the conditions of access to a pipeline system in advance of contract negotiations, as this knowledge will allow market participants to make informed supply and market decisions thereby contributing to the efficient functioning of the natural gas market. ${ }^{125}$

In numerous decisions regarding both oil and natural gas pipelines, ${ }^{126}$ the Board has emphasized the importance of transparency in negotiations with shippers regarding access to capacity and stated that shippers on all pipelines should be given the terms and conditions of access to a pipeline in advance of the open season, so that the shippers and the pipeline company would be on an "equal footing" in negotiations and that there would be no potential for an abuse of market power. ${ }^{127}$

In the Keystone Base, the NEB quoted the above passage from TransCanada GH-2-87. It stated that it requires open access to both oil and gas pipelines as "an important prerequisite to enable the effective and efficient operation of the market," access was particularly important for oil pipeline systems with contracted capacity. ${ }^{129}$

In the Northern Gateway Report, the Joint Review Panel (JRP) stated that one of the obligations of a common carrier is "to provide service with reasonable terms and conditions and to make these terms and conditions available to all categories of shippers and potential shippers in a clear and orderly way." "Accordingly, the JRP directed Northern Gateway to prepare a single document containing "all tariff-related matters." ${ }^{31}$ The JRP also underlined

National Energy Board, "Regulation of Traffic, Tolls and Tariffs," online: <www.neb-one.gc.ca/bts/ whwr/rspnsblt/trffctlltrff-eng.html\#s1> ["NEB Responsibilities"].

125 TransCanada PipeLines Limited: Applications for Facilities and Approval of Toll Methodology and Related Tariff Matters (July 1988), GH-2-87 at 92, online: online: NEB $<$ https://docs.neb-one.gc.ca/lleng/lisapi.dll?func $=1$ lworkspace $>$ [TransCanada GH-2-87] [emphasis in original].

126 See e.g. TransCanada PipeLines Limited North Bay Junction Application Responses of the Canadian Association of Petroleum Producers (CAPP) to Information Requests from the National Energy Board (NEB) (December 2004), RH-3-2004 at 6-7, online: NEB <https://docs.neb-one.gc.ca/ll-eng/llisapi.dll? func=llworkspace> [North Bay Junction]; Keystone Base, supra note 55 at 23. Keystone Base, ibid at 20.

Ibid.

Ibid. See also PanCanadian, supra note 40.

Considerations, supra note 65 at 353; National Energy Board, Connections: Report of the Joint Review Panel for the Enbridge Northern Gateway Project, vol 1 (Calgary: NEB, 2013) at 8. The Joint Review Panel was established by the National Energy Board and the federal Minister of the Environment to assess the environmental, social, and economic effects of the Enbridge Northern Gateway Project. Considerations, ibid at 353 . 
the importance of transparency of terms of access to the pipeline, stating: "Fairness requires that prospective shippers know the terms of access to a pipeline in advance of contracting for capacity. This knowledge will allow market participants to make informed supply, market, and transportation decisions, which will contribute to the efficient functioning of the petroleum market." ${ }^{\text {132 }}$

The foregoing discussion shows that the NEB approach to regulation of access to major oil pipelines is in accordance with the principles of economic theory stated above. A review of NEB decisions regarding access to capacity in oil pipelines is presented below. These decisions demonstrate that the NEB supports competitive markets but will adjudicate concerns raised by shippers or competing pipeline companies.

\section{FIRM CONTRACTS ARE NOT INCONSISTENT WITH COMMON CARRIAGE OBLIGATION}

The NEB has generally held that allocation of capacity to firm service is not inconsistent with the common carriage obligation of an oil pipeline pursuant to section 71(1) of the $N E B A$, provided that two criteria are met. The two criteria are:

1. The pipeline company must have held a fair and transparent open season whereby any interested shipper could commit to the Firm Service offered; and

2. A reasonable percentage of capacity must be reserved for uncommitted volumes or spot shipments. ${ }^{133}$

The determination of what is a reasonable percentage of uncommitted capacity is a matter for the NEB's judgment based on the circumstances of any specific case. ${ }^{134}$ In making this determination, the NEB has also considered whether the pipeline company is able to readily expand its facilities, for example, by the addition of pump stations. ${ }^{135}$ This approach is consistent with the broad discretion of the NEB regarding the common carriage obligation found in the initial wording of section 71(1).

\section{SeCtion 71(1) ReQUiREMENTS IN THE NEB FILING MANUAL}

For applications for exemptions from the common carriage requirement of section 71(1) of the NEBA, the Filing Manual requires that the applicant provide evidence that:

- an open season was held offering all of the capacity to be contracted to anyone interested in shipping; and

Trans Mountain Expansion, supra note 53; Keystone Base, supra note 55; Express Pipeline, supra note 75; Enbridge Southern Lights, supra note 40; Enbridge Bakken Pipeline Company Inc, on behalf of Enbridge Bakken Pipeline Limited Partnership (December 2011), OH-01-2011, online: NEB <https:// docs.neb-one.gc.ca/ll-eng/llisapi.dll?func=llworkspace> [Enbridge Bakken].

See e.g. Trans Mountain Pipeline ULC on behalf of Trans Mountain Pipeline, LP (1 December 2011), RH-2-2011, online: NEB <https://docs.neb-one.gc.ca/ll-eng/llisapi.dll?func=llworkspace > [Trans Mountain Westridge]; Keystone XL, supra note 54. 
- allowing the exemption is in the public interest. ${ }^{136}$

The Filing Manual also states that "[t]he open season must be conducted in a manner which provides all interested shippers the same opportunity to participate and allows adequate time for their consideration of the issues." 137 The Filing Manual indicates that the application should include detailed information regarding the open season as follows:

\footnotetext{
A subsection 71(1) application should include copies of all notices of the open season, the timing and method of providing notice, all correspondence between the pipeline and parties interested in contracting with the pipeline and any expressions of [interest] in or concerns regarding the application. The applicant should also provide an indication of the results of the open season and a sample or standard form contract to indicate the arrangements contemplated. $^{138}$
}

It appears that this portion of the Filing Manual is not currently used by the NEB; none of the NEB decisions reviewed refer to it. In addition, the Filing Manual does not reference the second of the two key criteria set out in the relevant NEB decisions for what are essentially exemptions from the requirements of section 71(1): that a reasonable percentage of capacity must be reserved for uncommitted or "spot" shipments, or, alternatively, that the facilities must be readily expandable.

\section{THE IMPORTANCE OF FIRM CONTRACTS FOR CAPACITY IN OIL PIPELINES IN THE CURRENT COMPETITIVE MARKET}

Most new pipelines today will compete for supply (shipper volumes) with an existing pipeline or pipelines. New pipeline projects require significant upfront investment. ${ }^{139}$ Parties have suggested that without firm commitments from shippers, new pipelines ${ }^{140}$ and pipeline expansions ${ }^{141}$ would not be built. Proponents of new pipelines will tend to offer lower tolls to shippers in order to entice them to ship on the new pipeline instead of an incumbent pipeline, which may have cost-of-service tolls. In exchange for the lower tolls and guaranteed or "unapportioned" access, the pipeline company will require the shipper to sign a firm service contract or Transportation Service Agreement (TSA). ${ }^{142}$ The firm service contracts, in turn, assist the pipeline company in acquiring financing for the pipeline by enabling it to demonstrate to banks and investors that volume risk is shared with shippers.

See National Energy Board, "Filing Manual - Guide S - Access on a Pipeline (NEB Act s.71)," online: $<$ www.neb-one.gc.ca/bts/ctrg/gnnb/ flngmnl/fmgds-eng.html> ["Filing Manual"]; National Energy Board, Appendix 1: Filing Manual Checklist at App-35, online: <www.neb-one.gc.ca/bts/ctrg/gnnb/ flngmnl/fmnnx1-eng.pdf $\$$.

"Filing Manual," ibid. Ibid.

J David Brett \& Nadine E Berge, "Oil and Gas Transportation: Is Contract a Viable Alternative to Traditional Regulation?" (2006) 44:1 Alta L Rev 93.

140 See e.g. Express Pipeline, supra note 75 at 44 . This was also true of the Alliance Pipeline: see generally Gordon Jaremko, "Proliferating Pipelines," Oilweek (5 November 2001) 49.

${ }_{141}$ See e.g. Trans Mountain Westridge, supra note 134, Trans Mountain said that in 2006, it had attempted to obtain shipper commitments to expand the pipeline, but it did not obtain sufficient support to proceed. The guarantee of unapportioned access means that if capacity on the pipeline becomes scarce and subject to apportionment (prorationing), the firm shippers' capacity will not be cut back, only uncommitted shippers will be prorationed. In some cases, firm shippers are also given renewal rights. 
Under a firm service contract, the shipper will commit to ship a specified volume of oil, natural gas, or other products for a specified number of years. If the shipper does not ship the volume of product specified in the firm service contract in a given month, the shipper remains obligated to pay the fixed toll component, which is essentially the reservation charge for the right to transport the oil or gas. For volumes actually transported, the shipper will also pay the variable toll component, which includes a charge for fuel used to operate the pump stations of an oil pipeline.

Industry representatives have indicated that the requirement for shippers to sign firm service contracts of 15 to 20 years is a major financial commitment on the balance sheet of a shipper. ${ }^{143}$ Oil producers may be required to sign firm service contracts for a specific volume before final financial information about construction costs and tolls on the proposed pipeline is available, and even before the producers know what their own requirements for additional capacity will be.$^{144} \mathrm{~A}$ shipper provided the following hypothetical example: if a shipper signed a firm service contract to ship $50,000 \mathrm{bpd}$ on an oil export pipeline at a toll of approximately $\$ 4.50$ per barrel, this would be a commitment to pay approximately $\$ 1.6$ billion over 20 years. A junior producer may not be able to access the financial backing required to make this size of financial commitment.

\section{NEB Decisions Regarding Firm Service in OIL PiPelines}

Most of the NEB decisions approving the allocation of firm capacity on oil pipelines relate to applications for new pipelines with competitive tolls that will compete with existing pipelines. ${ }^{145}$ The NEB has also approved the allocation of capacity to firm contracts on an existing pipeline, ${ }^{146}$ on an application for expansion of a pipeline, ${ }^{147}$ and on a line reversal. ${ }^{148}$

The Express Pipeline decision, in 1997, is the first approving the allocation of capacity to firm contracts on a new pipeline. ${ }^{149}$ The Express Pipeline would compete for supply from the WCSB with the existing Interprovincial Pipeline. Both pipelines started at Hardisty, Alberta. The Express Pipeline would transport oil to Casper, Wyoming, to access new markets in the US, while the existing Interprovincial Pipeline ran to Chicago, Illinois. The NEB ruled that the firm contracts negotiated by Express were not in contravention of its common carrier obligations.

This was a common sentiment expressed by shippers and other industry representatives. As part of the research performed for this article, representatives of major oil and gas pipeline companies and shippers, as well as industry associations and regulators, were interviewed. Parties interviewed requested that their identities be kept confidential. 


\section{REQUIREMENTS FOR OPEN SEASONS}

The requirement for a fair and transparent open season is a part of providing open access to transportation capacity. An open season must be done in a "fair and transparent manner"150 and all potential shippers must have a "fair and equal opportunity to participate." 151 In Express Pipeline, the NEB made the point that all shippers should be made aware that if they do not enter into firm service agreements, they will not get the same services as those entering into the firm service agreements. The phrase "open season" does not appear in the NEBA. ${ }^{152}$

Sometimes a pipeline company will have several rounds or stages of open seasons. The pipeline company may learn through a first stage of an open season that there is more demand for capacity than originally anticipated, or that shippers would prefer different terms and conditions of service than those offered. The NEB has approved a single-stage open season in the context of a line reversal, ${ }^{153}$ a two-stage open season in the context of a proposed pipeline, ${ }^{154}$ and a three-stage open season in the context of an application for expansion of capacity on an existing pipeline. ${ }^{155}$

\section{What Constitutes a Reasonable Percentage RESERVED FOR UNCOMMITTED VOLUMES?}

As noted above, the NEB has held that an oil pipeline company must reserve a "reasonable" percentage of capacity for uncommitted shippers to ensure compliance with common carrier obligations. In all except two of the NEB decisions reviewed, the NEB approved the percentage of capacity reserved for uncommitted shippers proposed by the pipeline company. Percentages approved range from 6 percent to 21 percent.

In the Vantage Pipeline decision, ${ }^{156}$ Vantage Pipeline Canada Inc. (Vantage) proposed to construct a pipeline to transport liquid ethane from North Dakota, US, through Saskatchewan, to interconnect with the Alberta Ethane Gathering System near Empress, Alberta. The NEB considered this pipeline to be an oil pipeline subject to section 71(1) of the NEBA. Vantage reserved 10 percent of the capacity of the pipeline for uncommitted shippers. The NEB found that this was reasonable, in part because Vantage had indicated that the capacity of the pipeline could be expanded if two additional pump stations were added.

In the Enbridge Bakken decision, 21 percent of the proposed Bakken Pipeline was reserved for uncommitted shippers. The NEB found that this was reasonable, in part because Enbridge had indicated that the capacity could be expanded should additional space be required by shippers. ${ }^{157}$

\footnotetext{
$150 \quad$ See e.g. Enbridge Bakken, supra note 133 at 22.

151 See e.g. Keystone Base, supra note 55 at 19; Enbridge Southern Lights, supra note 40.

$152 \quad$ Supra note 32 at 27.

153 See e.g. Enbridge Bakken, supra note 133.

$154 \quad$ See e.g. Enbridge Southern Lights, supra note 40.

155 See e.g. Trans Mountain Expansion, supra note 53

156 Vantage Pipeline Canada ULC (1 January 2012), OH-3-2011, online: NEB <https://docs.neb-one.gc.ca/ ll-eng/llisapi.dll? func=llworkspace $>$.

Enbridge Bakken, supra note 133.
} 
In the Keystone Base, at the time of the application, 22 percent of the capacity of the proposed pipeline was available for uncommitted shippers. ${ }^{158}$ However, Keystone appears to have anticipated future demands for firm service, because it only committed to reserve 6 percent of the nominal capacity of the pipeline for uncommitted volumes in the future. Keystone stated that if additional shipper demand were to materialize, it may offer a portion of the uncommitted capacity through a future open season. ${ }^{159}$ The NEB approved this arrangement, presumably in part because the capacity of the pipeline was readily expandable. A major factor in the NEB's approval of the capacity allocation in the Keystone Pipeline was that the shippers had voluntarily signed long-term firm transportation contracts. ${ }^{160}$

In Express Pipeline, 15 percent of the capacity of the proposed pipeline was reserved for uncommitted shippers. ${ }^{161}$ The NEB did not discuss the basis on which it found this to be reasonable.

In the decision in Trans Mountain Expansion, the NEB approved Trans Mountain's proposal to reserve 20 percent of capacity for uncommitted shippers. ${ }^{162}$ The Board noted that the proposed allocation was not opposed by any party to the proceeding and that this allocation "should provide shippers with adequate capacity on a monthly basis while allowing Trans Mountain to secure sufficient long-term volumes to support the investment required for the Expansion." 163

\section{Does THE NEB EVER Decline to APPROVE THE Amount OF CAPACITY RESERVED FOR UNCOMMITTED VOLUMES?}

While the range in percentages of capacity reserved for uncommitted shippers varies greatly, it is clear based on the decision Interprovincial Pipe Line of 1997 and the Keystone $X L$ that the NEB will exercise its discretion to require pipeline companies to change their tariffs to allocate a reasonable proportion of capacity to uncommitted shippers. It appears that the NEB may take a similar approach on Northern Gateway based on the draft conditions proposed by the JRP. ${ }^{164}$

\section{a. The Interprovincial Pipe Line Decision}

The Interprovincial Pipe Line decision deals with the original application for the approval of facilities and a tolling methodology in order to reverse the direction of flow of crude oil in Line 9 between Montreal, Quebec, and Sarnia, Ontario. ${ }^{165}$ Various refiners had signed firm contracts for 100 percent of available capacity. The NEB rejected the arrangement proposed by IPL, largely, it seems, because there were no transportation alternatives other than IPL available for shippers. The Board also noted that Line 9 represented "the only direct

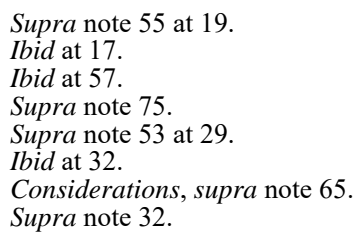


connection to bring offshore crude to the Ontario market." 166 The line had "low levels of contamination, and it was strongly preferred by the Ontario refiners." ${ }^{167}$ The NEB held that in order for IPL to meet its common carrier obligations, IPL would be required to keep available 20 percent of the capacity on the reversed Line 9 for monthly nominations. The NEB noted that although IPL had conducted an open season, there had been "considerable uncertainty as to whether the Board would approve the reversal, what the tolls would be, the costs to be underpinned by the [firm service contracts], timing of applications to the Board and reversal of the line." "68 The NEB was not convinced by IPL's assertion that expansion facilities could be added, noting that IPL had made no attempt to provide such service.

\section{b. The Three Keystone Decisions}

The Canadian portions of the Keystone pipeline system were approved in three separate NEB proceedings as follows:

1. Keystone Base, from Hardisty, Alberta, to Haskett, Manitoba, approved by the NEB in proceeding $\mathrm{OH}-1-2007 .{ }^{169}$

2. The Cushing Expansion, which added capacity to Keystone Base, approved by the NEB in proceeding $\mathrm{OH}-1-2008 .{ }^{170}$

3. Keystone XL, from Hardisty, Alberta, to Monchy, Saskatchewan, approved by the NEB in a decision in 2010 following proceeding OH-1-2009. ${ }^{171}$

In the Keystone Base and Cushing Expansion applications, the NEB approved the reservation of 6 percent of capacity for uncommitted volumes, as proposed by Keystone. In the Keystone XL proceeding, Keystone again proposed to reserve 6 percent of capacity for uncommitted volumes. During the proceeding, the NEB invited comments from the parties on a proposal to require Keystone to reserve 20 percent of the total capacity of the combined Keystone Base and Keystone XL pipelines for uncommitted volumes. Keystone responded that a reservation of 20 percent for uncommitted volumes was unnecessary as there would be sufficient pipeline infrastructure into the US midwest. Keystone also stated that there was a risk that the Keystone pipelines would be underutilized, and that reserving 20 percent of capacity for uncommitted volumes would give Keystone less flexibility in managing the underutilization risk. Keystone proposed instead that "a 10 per cent reservation could be accommodated." $" 172$

The NEB required that 12 percent of capacity should be reserved for uncommitted volumes. The NEB stated that the amount of capacity to be set aside for uncommitted

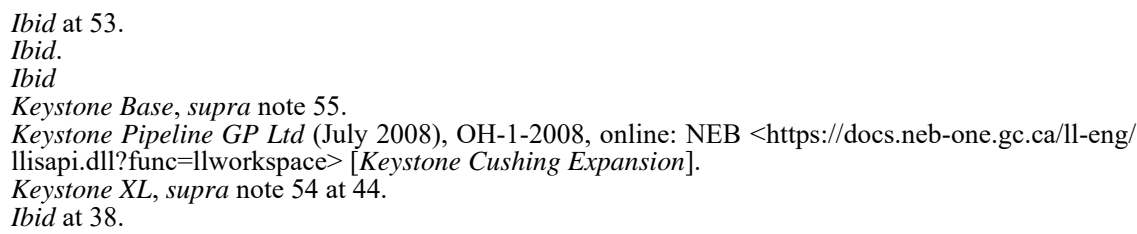


volumes "is a matter of judgment and based on the circumstances of any specific case."173 The NEB noted that the volumes identified by Keystone to be transported on the Keystone XL Pipeline had originally been used to justify the Cushing Expansion. The NEB found, based on Keystone's evidence, that having uncommitted capacity would allow Canadian producers "added flexibility to respond to market conditions and create opportunities to develop a broader range of U.S. customers and market opportunities." ${ }^{174}$ As a result, the NEB set the level of uncommitted capacity "at the higher end of the range," 175 based on the Canadian public interest. Basically, the NEB overruled the proponent's proposal for uncommitted volumes even though, in this case, no party other than Enbridge, TransCanada's competitor, had challenged the proposed allocation of 6 percent of capacity to uncommitted shippers. ${ }^{176}$

\section{c. Northern Gateway Report}

The Northern Gateway application is unusual in that it is the only current long-distance oil pipeline application in which the applicant did not require shippers to sign firm contracts prior to the filing of the application. ${ }^{177}$ Instead, the Funding Participants (shippers) had signed Funding Support Agreements by which they contributed over \$10 million each towards the regulatory costs of preparing and filing the application with the NEB. ${ }^{178}$ For each $\$ 10$ million unit of financial support, a Funding Participant received certain options, including an option to secure up to $50,000 \mathrm{bpd}$ of capacity on the oil pipeline at a lower toll. Shippers were reluctant to sign firm contracts in advance of the regulatory filing due to the uncertainty of obtaining a timely approval for a greenfield pipeline project in northern British Columbia. Part of that concern stemmed from anticipated opposition to the project from First Nations. Firm contracts will be signed well in advance of construction, should the project be approved.

In its application, Northern Gateway proposed to reserve 5 percent of the term shippers' committed volume for uncommitted shipments. ${ }^{179}$ The JRP, in a list of draft conditions for the pipeline, invited comments from parties on a possible requirement that 10 percent of capacity be reserved for uncommitted volumes. Northern Gateway objected to the 10 percent proposal, noting that increasing the capacity for uncommitted volumes would be unfair to the Funding Participants, who, in exchange for assuming part of the risk of the pipeline application, collectively had options to pay discounted tolls on 95 percent of the capacity of the pipeline.

Ibid.

Considerations, supra note 65 at 348.

Ibid.

Northern Gateway proposed to reserve 25,000 bpd of capacity for uncommitted volumes, which is equal to 5 percent of the term shippers' committed volume, or approximately 4.8 percent of the total capacity of the proposed oil pipeline of 525,000 bpd: ibid at 3,349 . 
The JRP noted that the proposed pipeline

[I]n providing access to Pacific Basin markets, would be a significant and strategic addition to the western Canadian pipeline system overall. In the Panel's view, it would provide producers with valuable flexibility in their transportation options and allow for the development of a significantly broader range of customers. From a public interest perspective, these factors would, in the Panel's view, suggest that the uncommitted reserve capacity proposed by Northern Gateway be increased. ${ }^{180}$

Despite this view, the JRP ultimately removed the 10 percent requirement from the conditions, likely because the Northern Gateway application discussed here is a facility application, and so conditions on tolling are inappropriate. The JRP concluded that it "continues to be of the view that meaningful access for uncommitted shippers to a system of the scale and strategic importance of Northern Gateway would entail reserve capacity for both the condensate import and the oil export pipelines of not less than 10 per cent."181

On 17 June 2014, the Governor-in-Council approved the Northern Gateway Project, subject to the 209 environmental, financial, and technical conditions set out by the JRP. ${ }^{182}$ A number of First Nations and environmental groups have commenced court actions challenging the Northern Gateway Project. ${ }^{183}$ In addition, the government of British Columbia has set out five conditions to be met on the Northern Gateway Project, including a condition requiring a fair share of the economic benefits of the pipeline for British Columbia. $^{184}$

The next regulatory step would be for Northern Gateway to file a tolling application with the NEB which would include an application for approval of the percentage of capacity to be reserved for uncommitted volumes. The above remarks appear to be a strong hint to Northern Gateway that it will have to build its justification for the 5 percent reservation or risk the imposition of a 10 percent reservation. If the NEB were to approve the 5 percent reservation it would be the lowest percentage ever approved by the NEB.

Ibid at 352 .

Ibid.

"Northern Gateway Decision Statement," supra note 65. The conditions include a requirement that Enbridge set aside $\$ 950$ million in liability coverage to cover costs of a potential spill: Jeff Lewis, "Northern Gateway pipeline approved by panel with 209 conditions," Financial Post (19 December 2013), online: $<\mathrm{http}$ ///business.financialpost.com/news/energy/northern-gateway-pipeline-approved-bypanel-with-209-conditions? lsa $=44 \mathrm{~b} 9$-edd $1>$.

183 Rowland J Harrison \& Gordon E Kaiser, "2014: The Energy Year in Review," Editorial (2015) 3:1

Energy Regulation Q 9 at 10; Gord Hoekstra, "First Nations challenge B.C. government in court over Northern Gateway pipeline," Vancouver Sun (14 January 2015), online: <www.vancouversun.com/ technology/First + Nations + challenge + government + court + over + Northern + Gateway + pipeline/ 107257 42/story.html>; Wendy Stueck, "B.C. First Nations challenge Northern Gateway pipeline in new court action," The Globe and Mail (14 July 2014), online: <www.theglobeandmail.com/news/britishcolumbia/first-nations-challenge-northern-gateway-pipeline-in-new-court-action/article19608617/>. The Federal Court of Appeal has granted leave to the Gitxaala First Nation to appeal the federal cabinet's approval of Northern Gateway: "Gitxaala First Nation granted leave to appeal Northern Gateway pipeline," CBC News (26 September 2014), online: <www.cbc.ca/news/canada/british-columbia/

184 gitxaala-first-nation-granted-leave-to-appeal-northern-gateway-pipeline-1.2779604>. Globe and Mail (17 June 2014), online: <www.theglobeandmail.com/news/british-columbia/bc-tonorthern-gateway-no/article19213866/>. 


\section{The Impact of Uncertainty Regarding the Percentage TO BE RESERVED FOR UNCOMMITTED VOLUMES}

The lack of predictability in the NEB's findings on the percentage of capacity in oil pipelines to be reserved for spot shippers can cause issues for pipeline companies and shippers. Prior to filing a tolling application with the NEB, a pipeline company will negotiate firm service contracts with shippers based on an assumption about how much capacity will be available for firm shippers. If the NEB decision requires that a greater percentage of capacity be reserved for spot shippers, the pipeline company may have to renegotiate contracts with firm shippers based on a smaller percentage of the volume being available for firm service. This can lead to delays in approval and construction of new pipelines that are urgently needed to provide additional take away capacity from the WCSB.

\section{E. Do Oil Pipeline Companies Today have Market Power?}

\section{The INDUSTRY PERSPECTIVE}

In conversations with major Canadian oil shippers, several themes emerged. Shippers noted that it was important that major pipeline companies, such as Kinder Morgan and Enbridge, construct oil pipelines as these companies have the experience and the ability to obtain the financing necessary to do so. Shippers indicated that additional oil pipeline capacity is required due to the differential between the price for crude oil sold in Alberta and the world price for oil. As a result, shippers indicated that they felt obligated to support all of the major proposed export pipeline projects - the Trans Mountain Expansion, Northern Gateway, Keystone XL, and Energy East - because of the uncertainty as to whether any or all of these projects will receive regulatory approval.

Shippers opined that pipelines still hold a natural monopoly and therefore the general absence of objections from shippers in tolling applications by pipeline companies to the NEB ought not to be taken as active support from the shippers for the tolls proposed by the pipeline company. Rather, they indicated that shippers had no choice but to go along with whatever tolls the pipeline company proposed, due to the high demand for capacity in oil export pipelines.

\section{TWO TRANS MOUNTAIN DECISIONS - \\ The 2011 Trans Mountain CAPACITy ReAllocation DECISION AND THE 2013 TRANS MOUNTAIN EXPANSION DECISION}

In most of the NEB proceedings, shippers do not tend to describe the pipeline on which they ship their products as a monopoly or criticize the approach of the pipeline company presumably because of the importance of pipelines to producers. Typically in NEB proceedings, shippers on a pipeline system will either intervene in support of the shipper's application or remain silent. However, shippers on the Trans Mountain pipeline have both criticized the approach taken by Trans Mountain and referred to Trans Mountain as a 
monopoly in two recent Trans Mountain proceedings. ${ }^{185}$ Trans Mountain Pipeline is unusual in that it is still the only oil pipeline to the west coast of Canada and it "serves a distinct market." ${ }^{186}$ As described earlier, other oil pipelines now face competition in their destination markets.

\section{a. The Trans Mountain Westridge Decision (RH-2-2011)}

The Trans Mountain Westridge decision is important for several reasons. First, it is the only case to date in which the NEB has approved the adoption of firm contracts on an existing oil pipeline as opposed to new pipelines or expansion of capacity on existing pipelines. In all other cases reviewed, NEB approval of the firm contracts was predicated on the need for firm shippers to underpin the capital costs of the capacity expansion or new facilities. Second, in this case, an approval was granted despite strenuous objections from existing shippers, which is unusual in pipeline applications.

The Trans Mountain pipeline has been regularly operating under apportionment since 2005. ${ }^{187}$ Shippers on the Trans Mountain pipeline system are divided into Land Shippers and Dock Shippers. The Land Shippers ship crude oil and refined petroleum products to destinations in British Columbia. They also ship crude oil to four Washington State refineries through a US affiliate at Sumas on the British Columbia-Washington State border. ${ }^{188}$ The Dock Shippers ship crude oil all the way to the Westridge Dock at Burnaby, British Columbia, on the west coast, where it is loaded into ocean tankers and barges and shipped to overseas markets, primarily in Asia. The Dock Shippers need to be able to ship volumes in "vessel-sized"189 increments equal to the capacity of the ocean tankers. They also need to coordinate their shipments with marine transportation schedules, and their shipments need to take place on an "all-or-nothing basis." 190 They needed firm service in order to meet these requirements and to enable them to develop new markets in Asia by guaranteeing the provision of certain volumes.

In order to accommodate the Dock Shippers' needs, Trans Mountain proposed to reallocate a portion of capacity from Land Shippers to Dock Shippers and to implement firm service for 68 percent of the Dock capacity. Firm Shippers would sign 10-year contracts and pay a premium for the privilege of receiving firm service, known as the "Firm Service Fee." 191 Trans Mountain proposed to use the Firm Service Fee "to advance incremental capital projects and conduct preliminary activities in support of a potential expansion of the [Trans Mountain] Pipeline." ${ }^{\text {"192 }}$ The payment of a higher toll for firm service is unusual in the Canadian context; on most oil pipelines, firm shippers pay reduced tolls in exchange for their long term commitment to ship specified volumes. Trans Mountain held an open season in which any party could subscribe to firm service to the Westridge Dock. Overall, 18 percent

See e.g. Trans Mountain Westridge, supra note 134 at 11; Trans Mountain Expansion, supra note 53 at 16.

Trans Mountain Westridge, ibid.

Ibid at 1 .

Ibid.

Ibid at 25 .

Ibid at 26 .

Ibid at 29 .

Ibid at 38 . 
of the pipeline would be subject to firm commitments and 82 percent would be available for uncommitted volumes. ${ }^{193}$

Several shippers on the Trans Mountain system objected to Trans Mountain's application. Imperial Oil argued that converting existing common carriage capacity to contract was inappropriate given the shortage in capacity and that "many shippers [had] based their investments and operations on the fundamental premise that the pipeline is a common carrier pipeline with no contract carriage." ${ }^{194}$ Chevron argued that Trans Mountain was a monopoly as it is the only oil pipeline to the west coast of Canada and it "serves a distinct market."195

Despite these objections, the NEB approved Trans Mountain's application. It noted that Trans Mountain now faced competition from current and future pipelines serving the WCSB, including those on which the NEB had previously approved some contracted capacity. It stated that the approval of firm service would help Trans Mountain to "retain volumes and lower its long-term volume risk." ${ }^{196}$ It noted that "[u]ncertainty in acquiring pipeline capacity to the Westridge Dock could be an obstacle" ${ }^{197}$ to developing important new offshore markets. The NEB noted again that it has a "wide discretion"198 in determining compliance with section 71(1) of the NEBA and that it is able to "tailor the statutory obligations to fit any unique circumstances which may exist." ${ }^{\prime 99}$ The remaining uncommitted capacity was held to be sufficient for Trans Mountain to meet its common carrier obligations.

The NEB noted that "shippers do not have any acquired rights to capacity on the Pipeline by virtue of past use." ${ }^{200}$ Therefore, it was acceptable for Trans Mountain to convert existing capacity to firm service.

\section{b. Trans Mountain Expansion Decision (RH-001-2012)}

The Trans Mountain Expansion decision is significant because it shows the importance the NEB places on signed agreements between sophisticated shippers and pipeline companies as evidence that the market is working properly and that there is no need for intervention from the NEB. The NEB approved the Trans Mountain toll methodology even though two current shippers on Trans Mountain complained to the NEB about the negotiation process. However, the NEB will strike down a provision in an agreement requiring shippers to abstain from complaining to the NEB.

In this proceeding, Trans Mountain Pipeline ULC (Trans Mountain) applied for approval of the toll methodology and the terms and conditions that would apply to a proposed 
expansion to the Trans Mountain pipeline. After the expansion, the Trans Mountain pipeline system would have a capacity of approximately 890,000 bpd. ${ }^{201}$

In the open season process, Trans Mountain required shippers to sign confidentiality agreements, which meant that the shippers could not discuss with other shippers their negotiations with Trans Mountain. ${ }^{202}$ In response to comments made by shippers, Trans Mountain made changes to the documents to be signed by shippers - the Facilities Support Agreement (FSA) 203 and the Transportation Service Agreement (TSA) - as well as to the Rules and Regulations of the Tariff. ${ }^{204}$ Trans Mountain argued that the fact that they had made changes as a result of shipper comments showed that there was "give-and-take" in negotiations and that they had not exerted market power over shippers. ${ }^{205}$ Trans Mountain initially received qualifying commitments for firm service from nine shippers.

Suncor Energy Products Partnership (SEPP) filed a complaint with the NEB regarding a requirement in section 2.2 of the FSA for shippers to provide support and cooperation and not to oppose Trans Mountain's efforts to obtain regulatory approvals. The NEB struck down section 2.2, stating that it is key to the Board's process that shippers are able to raise concerns about tolls and tariffs. ${ }^{206}$ After the Board's ruling, four additional shippers Suncor Energy Marketing Inc., SEPP, Total E\&P Canada Ltd. (Total), and Canadian Natural Resources Ltd. - made firm commitments to ship specified volumes on the proposed expansion. This suggests that section 2.2 may have prevented these shippers from committing to earlier volumes on the pipeline. As a result of the additional interest expressed, Trans Mountain increased the proposed capacity of the project to $890,000 \mathrm{bpd}$.

In the NEB proceeding, both Suncor and Total argued that given the lack of alternatives in transportation from the WCSB to the west coast of Canada and therefore in access to Asian markets, shippers were forced to accept unfair negotiating conditions and unjustly high tolls. Suncor explained that crude oil prices in Asian markets are significantly higher than in the interior of North America, ${ }^{207}$ that there had been high levels of apportionment on the Trans Mountain Pipeline System, and that WCSB producers were facing price discounts in the range of $\$ 20$ to $\$ 30$ per barrel because of the lack of access to Asian markets. ${ }^{208}$ Suncor argued that these factors meant that Trans Mountain could exert significant market power during open season negotiations. Other possible alternatives were not economically feasible given that shippers could receive substantially higher netbacks shipping on the Trans

Trans Mountain filed its facilities application for the expansion with the NEB on 16 December 2013. The NEB oral hearing on the facilities application has been postponed as of 21 August 2015: see National Energy Board, News Release, "NEB postpones Trans Mountain Expansion oral hearings" (21 August 2015), online: $<$ news.gc.ca/web/article-en.do?nid=1015719>.

Trans Mountain Expansion, supra note 53.

By signing a FSA, a shipper commits to sign a TSA provided that certain conditions precedent are met: see ibid. Trans Mountain Pipeline ULC, Application for Approval of the Transportation Service and Toll Methodology for the Expanded Trans Mountain Pipeline System (RH-001-2012) (29 June 2012), Appendix 7 at 14, online: NEB <https://docs.neb-one.gc.ca/ll-eng/llisapi.dll?func=llworkspace> [Application] (Facility Support Agreement).

Application, ibid at para 19.

Trans Mountain Expansion, supra note 53 at 15.

See Suncor Energy Products Partnership (SEPP) Application Regarding Trans Mountain Pipeline ULC (Trans Mountain) Open Season National Energy Board (Board) Decision (12 August 2012), (Letter Decision), online: NEB $<$ https://docs.neb-one.gc.ca/ll-eng/llisapi.dll?func=llworkspace $>$.

Trans Mountain Expansion, supra note 53 at 16.

Ibid at 4, 7 (Evidence of Suncor Energy Marketing Inc and Suncor Energy Products Partnership). 
Mountain system. Due to Trans Mountain having control over the decision whether or not to proceed with the expansion, it was understandable that Western Canadian oil producers would decide to pay the excessive tolls proposed by Trans Mountain.

Total also objected to the application despite having signed a commitment to firm service. Total argued that the open season process was neither fair nor transparent, that the NEB had insufficient information before it to determine whether the rates proposed by Trans Mountain were just and reasonable, and that the commercial basis for the project should be improved, among other things. Total argued that the discounted oil price differential and the limited number of alternatives for transporting oil had forced shippers to agree to high fees and tariffs. ${ }^{209}$ Possibly out of concern that Trans Mountain would decide not to proceed with the proposed capacity expansion, Total did not request a completely new negotiation process but simply an order that negotiations be extended to ensure that the negotiated settlement would be consistent with the Board's Guidelines for Negotiated Settlements of Tolls, Traffic and Tariffs.

George Schink, an economist testifying as an expert witness for Trans Mountain, argued that Trans Mountain faced competition from transportation of crude oil by rail and from both existing and proposed pipelines. He stated that Trans Mountain faced origin market (supply) competition from the Enbridge mainline and the Express-Platte pipeline system as well as Keystone Base. ${ }^{210} \mathrm{He}$ also stated that Trans Mountain faced future competition from the proposed Enbridge Northern Gateway and Keystone XL pipelines, the proposed Energy East project, and potential additional rail crude oil takeaway capacity.

As noted above, the NEB approved Trans Mountain's proposed allocation of capacity. ${ }^{211}$ The NEB noted that shippers were using rail and alternative pipelines as alternatives to Trans Mountain, which meant that Trans Mountain's market power was limited. ${ }^{212}$ The NEB also stated that both Keystone XL and Northern Gateway were already "sufficiently developed as potential alternatives to the Trans Mountain pipeline to act as limiting factors on the market power of Trans Mountain."213

Surprisingly, perhaps, the NEB held that the Open Season process undertaken by the pipeline company was fair, transparent, and appropriate. ${ }^{214}$ The NEB was not concerned about the fact that Trans Mountain had met with shippers one by one and had prevented shippers from discussing the negotiations among themselves. The NEB accepted Trans Mountain's evidence that confidentiality agreements are common in the industry and that they "do not taint the fairness of the negotiation process if the Open Season process is fair and transparent." 215

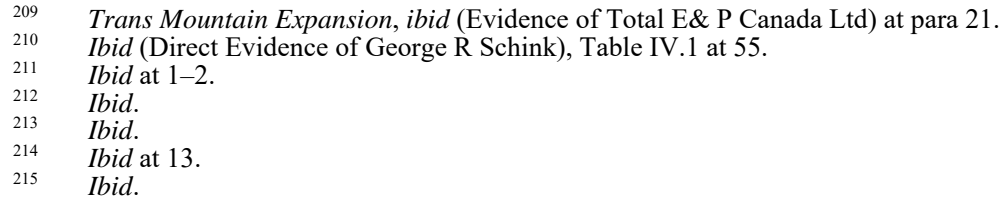




\section{c. Industry Perspective on the Trans Mountain Expansion Decision}

A pipeline company representative that was interviewed noted that in negotiations with shippers, shippers alternated between wanting to have the strength in negotiations afforded by co-operation with other shippers and wanting to keep confidential their commercial information such as monthly volumes nominated and maximum capacity of receipt points (such as refineries) for competitive reasons. In the majority of NEB oil pipeline cases reviewed, the pipeline company negotiated with shippers as a group and did not require shippers to sign agreements preventing them from talking to each other about negotiations.

A representative of a shipper interviewed surmised that if the NEB had struck down the tolls of Trans Mountain as not being just and reasonable, or required Trans Mountain to reopen negotiations with shippers, it ran the risk of having Trans Mountain decide not to proceed with the expansion because it would not provide an adequate rate of return for its investors. Given the importance of the expansion to the Canadian economy, the NEB appears to have decided that it was appropriate to interfere as little as possible with the commercial decisions made by Trans Mountain and by shippers signing FSAs.

\section{F. LOWER FIRM SERVICE TOLLS FOR COMMITTED SHIPPERS ARE NOT UNJUST DISCRIMINATION}

Pursuant to section 67 of the NEBA, tolls and service must not be unjustly discriminatory. ${ }^{216}$ In PanCanadian, the NEB stated that the question of what constituted "unjust discrimination" was a matter for the "considered judgment" of the Board. ${ }^{217}$ Section 63 of the NEBA provides that a determination by the NEB regarding whether there is unjust discrimination in a given case is a question of fact. ${ }^{218}$

The NEB has held that lower tolls, renewal rights, and unapportioned access for committed shippers are not unjust discrimination. ${ }^{219}$ This is because the firm shippers provide support for the financing of the pipeline and share the financial risk of the new pipeline with the pipeline company. In finding that lower tolls for firm service are not unjustly discriminatory, the NEB has taken into consideration the fact that a number of sophisticated shippers had executed firm service agreements. ${ }^{220}$

In Express Pipeline, as in Trans Mountain Expansion, the NEB noted that contract shippers are not prevented from filing complaints with the Board as a result of their contractual commitments made to the pipeline company, and that the NEB continues to be

NEBA, supra note 32, s 67 states: "A company shall not make any unjust discrimination in tolls, service or facilities against any person or locality.... Tolls must also be just and reasonable." Section 62 states: "All tolls shall be just and reasonable, and shall always, under substantially similar circumstances and conditions with respect to all traffic of the same description carried over the same route, be charged equally to all persons at the same rate" (ibid, s 62). Supra note 40 at 12

NEBA, supra note 32, s 63 states: "The Board may determine, as questions of fact, whether or not traffic is or has been carried under substantially similar circumstances and conditions referred to in section 62 , whether in any case a company has or has not complied with the provisions of that section, and whether there has, in any case, been unjust discrimination within the meaning of section 67" (ibid, s 62).

See e.g. Federated, supra note 40 at 10; Express Pipeline, supra note 75 at 23; Enbridge Bakken, supra note 133 .

See e.g. Trans Mountain Expansion, supra note 53. 
responsible to ensure that tolls are just and reasonable for both contract and uncommitted shippers.

In Enbridge Bakken, the Board noted that no party had raised concerns about the higher tolls to be paid by uncommitted shippers. ${ }^{221}$ The Board found that the toll differential between uncommitted and committed shippers would not result in unjust discrimination. The Board added:

The Board recognizes that Enbridge Bakken is operating in a very competitive environment. The Project is considered commercially at-risk, with only a portion of that risk being offset through the existence of longterm transportation contracts. The Board accepts that uncommitted shippers are charged a higher toll than shippers who have signed TSAs. ${ }^{222}$

In the Keystone XL decision, the NEB approved tolls for uncommitted shippers that were 20 percent higher than firm shippers with a ten-year contract, with tolls for firm shippers decreasing over the length of the contract term. ${ }^{223}$ The Board noted that these tolls were "market-based rather than cost-based and ... the result of negotiations between sophisticated parties." 224 The Board accepted that "this is a reflection of shippers having provided differing levels of financial support to the Keystone XL Project and accepting differing levels of risk" ${ }^{\prime 25}$ and that this toll structure was just and reasonable.

In Trans Mountain, the NEB held that the additional fee for firm service complied with the requirements of section 62 of the NEBA that tolls must be just and reasonable and section 67 of the NEBA that tolls not be unjustly discriminatory. The NEB's reasoning was based largely on the fact that the Firm Service Fee was established "following an open, transparent and fair Open Season process where all potentially interested commercial parties were invited to participate."226

\section{G. UniQue CaSes Regarding CAPACITy IN OIL Pipelines AND THE NEB APPROACH}

The desire of the NEB to support functioning competitive markets is also evident in two other decisions worthy of discussion. The first, the Chevron Priority Destination Designation Application, ${ }^{227}$ relates to the NEB interpretation of a provision in the Trans Mountain tariff regarding capacity. The second relates to an application by Trans-Northern Pipelines Inc. (Trans-Northern) for relief from its common carriage obligations.

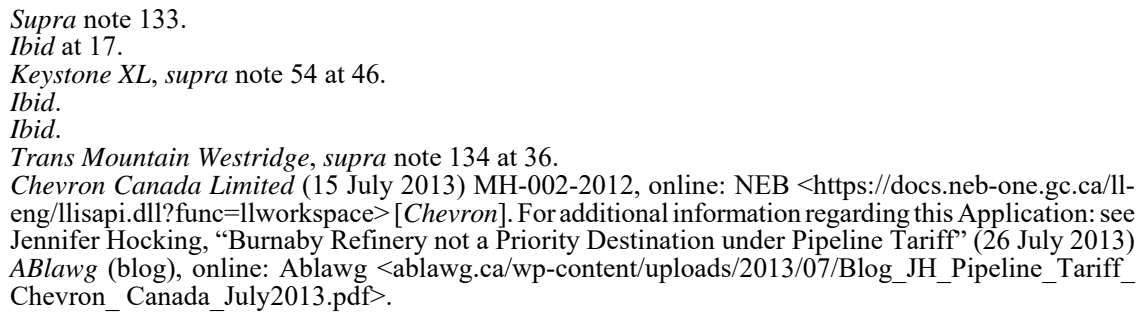
eng/llisapi.dll? func=llworkspace $>$ [Chevron]. For additional information regarding this Application: see Jennifer Hocking, "Burnaby Refinery not a Priority Destination under Pipeline Tariff" (26 July 2013) ABlawg (blog), online: Ablawg < ablawg.ca/wp-content/uploads/2013/07/Blog_JH_Pipeline_Tariff_ Chevron_Canada_July2013.pdf $>$. 


\section{CheVron Priority Destination Designation Decision}

In this proceeding, Chevron applied for a designation of its Burnaby oil refinery as a "Priority Destination" pursuant to the Tariff on the Trans Mountain Pipeline (Trans Mountain Tariff). ${ }^{228}$ The Trans Mountain Pipeline had been under apportionment since 2010, meaning that Uncommitted Shippers (shippers that did not sign long-term contracts with the Pipeline) have only been able to ship proportionally lower volumes of crude oil than the volumes they nominated.

"Priority Destination" is defined under section 1.58 of the Trans Mountain Tariff as a "refinery, marketing terminal or other facility connected to and capable of receiving petroleum from ... the Trans Mountain Pipeline ... and so designated by the [NEB] by reason that it is not capable of being supplied economically from alternative sources." 229 The Trans Mountain Tariff stipulates that in times of apportionment, available capacity will be allocated first to Firm Shippers (shippers that signed long-term contracts with the Pipeline). ${ }^{230}$ Of the remaining capacity, Uncommitted Shippers nominating to Priority Destinations will have priority over all other nominations. ${ }^{231}$

Chevron did not have firm service on the pipeline. ${ }^{232}$ While Chevron had explored other alternatives to the Trans Mountain Pipeline, it stated that it would have to incur substantial capital costs and to pay transportation operating costs that would be about five times higher than the transportation costs pursuant to the Trans Mountain Tariff.

The NEB denied the application. It noted that other refiners served by Trans Mountain had used several different supply options in order to mitigate supply risk and that Chevron also had a responsibility to establish alternative supply options. ${ }^{233}$

In effect, the NEB's message to Chevron was that it could not rely on a regulated solution where there were market options available.

\section{THE TRANS-NORTHERN DECISION}

The Trans-Northern proceeding is the only oil pipeline decision that contains the NEB's views on the interpretation of section 71(3) of the NEBA under which the NEB may require a pipeline company to construct new facilities. The Trans-Northern decision deals with a plan by Trans-Northern to decommission the Don Valley Lateral, a pipeline to the Toronto Harbour. Trans-Northern planned to decommission the line because it was costing in excess of $\$ 500,000$ per year to operate while generating only $\$ 70,000$ in revenues, with no potential for increased revenues. ${ }^{234}$ Roy-L was the only shipper to express concern about the

Trans Mountain Pipeline ULC, Petroleum Tarriff, No 92 (14 May 2013), online Kinder Morgan http://www.kindermorgan.com/content/docs/NEB_Tariff_No_92.pdf [Trans Mountain Tariff] . Ibid, s 1.58 .

Ibid, s 14(a).

Ibid, s 14(b).

Trans Mountain Expansion, supra note 53 at 11. This may be because Chevron's view was that the pipeline ought to continue to accept all oil tendered, and that the pipeline ought to have expanded: see Trans Mountain Westridge, supra note 134 at 17.

Chevron, supra note 227.

Trans-Northern, supra note 37. 
suspension of service. Based on a request from Roy-L, the NEB ordered Trans-Northern to file an application which would establish whether it should be granted relief from its common carrier obligations pursuant to section 71(1), and whether it should be required to maintain suitable facilities pursuant to section $71(3){ }^{235}$

Roy-L had access to truck and marine transportation alternatives, although trucking would cost more than shipping the petroleum products by pipeline, and marine delivery was "generally not an economically viable option." 236 Roy-L argued, based on the wording of section 71(3), that the test to be applied by the NEB in interpreting section 71(1) was whether the continuation of the common carrier obligation would place an undue burden on the oil pipeline company.

The NEB disagreed. The wording and purposes of sections 71(1) and (3) are different. Section 71(3) gave the Board the "extraordinary power to order a company to provide new facilities." 237 In applying section 71(3), the Board noted that "the burden on a [pipeline] company would be one relevant factor to be considered and balanced with any other existing public interest factors in determining what is reasonable in the circumstances." 238

As in the cases cited above, the NEB asserted that compliance with the common carrier provisions of section 71(1) should be determined by "a test of reasonableness, which permits the Board to tailor the statutory obligations of an oil pipeline to fit any unique circumstances that may exist." 239 The NEB granted Trans-Northern relief from section 71(1), and did not require Trans-Northern to provide facilities pursuant to section 71(3), again allowing market forces to operate.

\section{Conclusions}

The NEB's approach to allocation of capacity is consistent with economic theory and with the three economic objectives for regulation of oil pipelines described above. First, in allowing functioning oil transportation markets to work without interference, the NEB is seeking to "produce the same results as would be produced by effective competition, if it were feasible." ${ }^{240}$ Second, the NEB "requires that pipeline companies operate according to the principle of "open access." 241 Third, the NEB does not generally prevent entry of new pipeline companies into the oil pipeline transportation market.

Today, the majority of capacity in NEB-regulated major oil pipelines is subject to firm long-term contracts. The amount of capacity the NEB has required pipeline companies to reserve for common carriage or uncommitted volumes ranges from 6 percent to 21 percent. It is difficult to predict what percentage of capacity the NEB will require to be reserved for uncommitted volumes in new oil pipelines. Nor can it be stated that in all cases the NEB will simply approve the percentage applied for. 
Pipeline companies negotiating firm service contracts with shippers have to guess what capacity they will be required to reserve. If their guess proves inaccurate, they may have to go back to firm shippers and renegotiate volumes after an NEB decision, which could lead to substantial delays in the approval and construction of needed export pipelines. In order to provide clarity and transparency for all parties, it is recommended that the NEB create a written policy or Memorandum of Guidance (MOG) $)^{242}$ regarding access to oil pipelines.

No legislative amendments would be required for the NEB to adopt a Draft MOG. ${ }^{243}$ The requirement in section 71(1) of the NEBA that all oil pipeline companies are required to transport all oil offered to them is "subject to such exemptions, conditions or regulations as the Board may prescribe." 244 Thus, the NEB has the power to adopt policy directives such as the Draft MOG to indicate how it will likely exercise its discretion.

It is also recommended that the NEB Filing Manual and definition of common carriers be updated.

\section{A. RECOMMENDATIONS FOR A DRAFT MEMORANDUM OF GUIDANCE (MOG)}

\section{Proposed LANGUAGE FOR A DRAFT MOG}

The Draft MOG could state as follows:

An oil pipeline company may apply, pursuant to section 71(1) of the $N E B A$, for a partial exemption from its common carrier obligations provided that it meets the following conditions:

1. The pipeline company must demonstrate that it has held a fair and transparent open season providing all potential shippers with a fair and equal opportunity to participate.

2. The presumption will be that 5 percent of the capacity of the proposed pipeline or pipeline expansion must be reserved for uncommitted volumes, unless one of the following two conditions applies:

a. the pipeline company can demonstrate that it can readily expand capacity if there is further demand for capacity; or

b. a directly affected shipper or the proponent pipeline company can demonstrate to the satisfaction of the NEB that the circumstances of a particular case justify a higher or lower percentage of uncommitted capacity. how the NEB intends to interpret its mandate with respect to a particular issue. The NEB generally consults with affected parties prior to implementing a MOG or other policy changes. 


\section{CONSUltation}

The NEB should consult with affected parties, including shippers, producers, oil pipeline companies, and downstream customers such as refiners and local distribution companies, on the draft MOG. The Draft MOG set out above could be used as a starting point for industry consultation. Consultation should include a discussion on the benefits and impacts of a presumption of 5 percent reservation of capacity for uncommitted volumes. It should also include a discussion of possible implementation dates for the MOG.

\section{RATIONALE FOR RECOMMENDATIONS}

Paragraph 1 of the Draft MOG codifies the NEB's current requirement for an open season. The requirement for an open season supports fairness, transparency, and competition by ensuring that interested shippers have an opportunity to obtain service. It supports the principle of open access to capacity in oil pipelines by ensuring that shippers know the terms and conditions of access before entering into contract negotiations with pipeline companies.

The reservation of a portion of capacity for uncommitted volumes is important to ensure that new shippers and junior producers have the potential to access pipeline capacity. New producers may not have been in existence at the time of an open season, and junior producers may not have the financial backing available to them to participate in an open season. If no capacity were reserved for new producers and junior producers, this could limit incentives for new producers to enter the crude oil supply market and hence limit competition in those markets.

The presumption that 5 percent be reserved for uncommitted volumes is 1 percent below 6 percent, 6 percent being the lowest reservations approved by the NEB, in the Keystone Base $^{245}$ and Cushing Expansion ${ }^{246}$ decisions. In today's competitive crude oil transportation environment, pipeline companies that have firm contracts for the majority of capacity will be able to more easily obtain the financing necessary to construct new pipelines. The construction of additional pipelines to the west and east coasts of Canada, and to the Gulf of Mexico, would enable Canadian oil reach new overseas markets. The export of oil is important for both the Canadian and Alberta economies. The new pipelines proposed will tend to operate in competitive transportation markets, meaning that shippers will likely have a choice of transportation options. The reservation of capacity for uncommitted volumes (common carriage) is primarily necessary where there is no competition or no other option for shippers. If both Northern Gateway and the Trans Mountain Expansion are constructed, they will compete in providing access to Asian markets, providing options to shippers. If Keystone XL and Energy East are also constructed, there will be further competition for supply from the WCSB. Five percent is merely a presumption; the NEB would hear arguments from proponents and directly affected shippers in cases where a higher or lower percentage reservation may be appropriate. 


\section{B. ConcLusions}

This article has explained that it is important for the economies of Canada and Alberta to have additional export capacity in oil pipelines. In regulating access to oil pipelines, the NEB supports well-functioning competitive markets. The NEB will generally approve the allocation of capacity in oil pipelines to firm contracts provided that a reasonable percentage of capacity is allocated to uncommitted volumes (common carriage) and that a fair and transparent open season was held. The NEB supports open access to crude oil pipelines. The NEB will exercise its discretion in regulating access to pipelines when markets are not functioning properly. As more competition develops in crude oil transportation, a lower percentage of capacity allocated to uncommitted volumes or common carriage may be appropriate. The draft MOG proposed above would be helpful to shippers, producers, and pipeline companies in providing greater certainty and transparency to the NEB approach regarding approval of firm contracts on oil pipelines, while preserving the NEB's broad discretion in this area. 